\title{
Multiple Generations of Wolframite Mineralization in the Echassieres District (Massif Central, France)
}

\author{
Loïs Monnier ${ }^{1}$, Stefano Salvi ${ }^{1, * \mathbb{C}}$, Jérémie Melleton ${ }^{2}$, Laurent Bailly ${ }^{2}$, Didier Béziat ${ }^{1}$, \\ Philippe de Parseval ${ }^{1}$, Sophie Gouy ${ }^{1}$ and Philippe Lach ${ }^{2}$ \\ 1 Géosciences Environnement Toulouse (GET), CNRS, IRD, UPS, CNES. Université de Toulouse, \\ 31400 Toulouse, France; loismonnier@yahoo.fr (L.M.); didier.beziat@get.omp.eu (D.B.); \\ philippe.deparseval@get.omp.eu (P.d.P.); sophie.gouy@get.omp.eu (S.G.) \\ 2 Bureau de Recherches Géologiques et Minières (BRGM), 3 Avenue Claude Guillemin, 45000 Orléans, France; \\ j.melleton@brgm.fr (J.M.); 1.bailly@brgm.fr (L.B.); p.lach@brgm.fr (P.L.) \\ * Correspondence: stefano.salvi@get.omp.eu
}

Received: 4 September 2019; Accepted: 14 October 2019; Published: 17 October 2019

check for updates

\begin{abstract}
The Echassières district in central France contains complex rare-element ore deposits, whose formation is related to exotic igneous events and several hydrothermal episodes that are not entirely understood to date. Tungsten mineralization consists of three generations of wolframite, characterized by distinct $\mathrm{Fe} / \mathrm{Mn}$ ratios $(8.4 ; 3.5$ and 0.3 , for wolframite $a, b$ and $c$, respectively), formed during three separate hydrothermal episodes related to the Variscan orogeny. Wolframite $a$ occurs in quartz veins of the La Bosse stockwork where it crystallized before the Barrovian metamorphism that affected these veins and the host rock. After metamorphism, before intrusion of the Beauvoir and Colettes granites, wolframite $b$ crystallized in the stockwork during massive topazification. High concentrations of wolframite $c$ occur in the proximal quartz veins in the Mazet area, while only scant amounts are found in the La Bosse stockwork. In both settings, wolframite $c$ precipitated from the fluid responsible for greisen alteration that massively affected the Beauvoir granite. In the La Bosse stockwork, greisen alteration is characterized by hydrothermal topaz that is texturally and chemically distinct from that precipitated during topazification. Supergene alteration responsible for kaolinization of Beauvoir and Colettes granites caused remobilization of a non-negligible amount of tungsten (W) during replacement of wolframite by W-rich goethite in all units of the Echassières district. This model for multiple $\mathrm{W}$ mineralizing events is novel and can prove essential in distinguishing potential economic deposits worldwide.
\end{abstract}

Keywords: wolframite; W mineralization; greisen; beauvoir granite; topaz; W-rich goethite; hydrothermal alteration

\section{Introduction}

In a modern context of growing demand for high-technology metals to face the energetic transition, the European commission has listed a number of metals that are considered of critical supply in the near future [1,2]. Tungsten is one of the most critical of these metals.

The most common primary sources of $\mathrm{W}$ are skarn and stockwork deposits related to peraluminous granites [3]. These can occur in a variety of geodynamic settings related to plates convergence, i.e., anorogenic magmatism, cordillera-type arc environments (porphyry setting), and mostly collisional setting either during onset or collapsing stages [4-7]. Although it is recognised that wolframite mineralization in stockwork is commonly associated to greisen alteration ("an assemblage of quartz plus muscovite, accompanied by varying amounts of other distinctive minerals such as fluorite, topaz and tourmaline" [8]) in underlying granites, the genetic link between wolframite mineralization and greisen 
fluids is still being discussed by some authors [9-13], in particular because wolframite is only rarely observed within the greisen itself (e.g., in the Erzgebirge [14]). Indeed, Lecumberri-Sanchez et al. [15] highlight that $\mathrm{Fe}$ and $\mathrm{Mn}$, necessary for effective wolframite crystallization, mostly originate from the schist host rock, which would explain the fact that wolframite is commonly restricted to quartz veins located in the host rock. Nevertheless, numbers of recent studies, particularly on Asian $W$ mineralizations, have underlined the role of greisen and propose that $\mathrm{W}$, as other high field-strength elements (e.g., $\mathrm{Nb}, \mathrm{Ta}, \mathrm{Sn}$ ), derive in part or totally from greisen fluids [6,16-19]. Their greisen-related model is similar to that proposed for $\mathrm{W}$ deposit in Cornwall [20-22], where wolframite-bearing quartz veins and greisen alteration are linked by the occurrence of well-developed greisen alteration in the selvages of the mineralized veins, as well as by similar characteristics of fluid inclusions in the veins and in the greisen alteration. The Echassières district, in the French Massif Central, is an ideal setting to explore this problem as it presents a multitude of textural evidence pointing to at least a couple of $\mathrm{W}$ mineralizing events [23]. In addition, a recent study has been able to tie the origin of some wolframite-bearing quartz veins to the greisen fluid [24], thus providing an additional constraint on their origin. Although the magmatic and post magmatic processes involved in these mineralizations have been the focus of several studies [23-31], many are old, and the complexity of the system is such that data may be contradictory, and a clear interpretation of the Echassières mineralization is still a challenge.

In this paper, we report a detailed study on the $\mathrm{W}$ mineralization in the complex Echassières system. Using precisely defined paragenetic relationships and mineralogical compositions we are able to demonstrate the existence of three episodes of $\mathrm{W}$ mineralization related to three distinct geological events. Recognition of multistage mineralizing episodes such as evidenced here may bear important implications for exploration, as such complex processes may be key to high-grade endowments.

\section{Geological Setting}

The French Massif Central is composed for the most part of three metamorphic units, the Lower Gneiss Unit (LGU), the Upper Gneiss Unit (UGU) and the Para-Autochthonous Unit (PAU), intruded by several Variscan granitic systems emplaced from ca. 360 to 290 Ma. In the northern part of the Massif Central, these three units are superposed [32,33], forming what is known as the Sioule series, bounded to the west by the major Sillon Houiller strike-slip fault, to the south by the Saint-Gervais granite, to the north by migmatite and granite of Tréban, and to the east by Cenozoic sediments. The Sioule series display Barrovian metamorphism, with maximal recorded temperatures and pressures of ca. 600 and $700{ }^{\circ} \mathrm{C}, 7$ and $10 \mathrm{kbar}$, for LGU and PAU, respectively [34,35]. The age of metamorphism is controversial, with two dates, obtained by electron probe U-Th-Pb analysis on monazite, of ca. $335 \mathrm{Ma}$ and 360 Ma by Schulz [35] and Do Couto et al. [36], respectively, although the latter is probably more valid, as it is obtained using a better statistical treatment of the data. The series consists of two major antiforms; the central parts of each structure, which consist of PAU units, are intruded by peraluminous granites. The Pouzol-Servant laccolith occurs in the southern antiform, whereas the northern antiform, located in the Echassières district, hosts the more evolved granitic plutons of Colettes and Beauvoir.

The Beauvoir pluton is a world-class rare-metal hololeucogranite, in regard of its highly evolved chemistry derived by a combination of extreme magmatic fractionation [27] and incorporation of important quantity of meteoric water at late magmatic stages [28]. This granite has been the object of numerous studies [23-31] although its age of emplacement is still debated. Duthou and Pin [26] obtained $312 \pm 8 \mathrm{Ma}$ with the Rb-Sr method on bulk rock, confirmed by the value of $308 \pm 2 \mathrm{Ma}$ reported later by Cheilletz et al. $\left({ }^{40} \mathrm{Ar}-{ }^{39} \mathrm{Ar}\right.$ on lepidolite [29]). More recently, Melleton et al. dated it at $317 \pm 6 \mathrm{Ma}$ using $\mathrm{U}-\mathrm{Pb}$ isotopic systematics on colombite-group minerals [37]. The Beauvoir granite is genetically linked to the less evolved, much larger two-mica Colettes granite (312 $\pm 8 \mathrm{Ma} \mathrm{Rb}-\mathrm{Sr}$ on whole rock [31]). Both granites crosscut the wolframite-bearing La Bosse stockwork and are themselves crosscut by several quartz veins (Figure 1), termed 'proximal veins' [24]. 


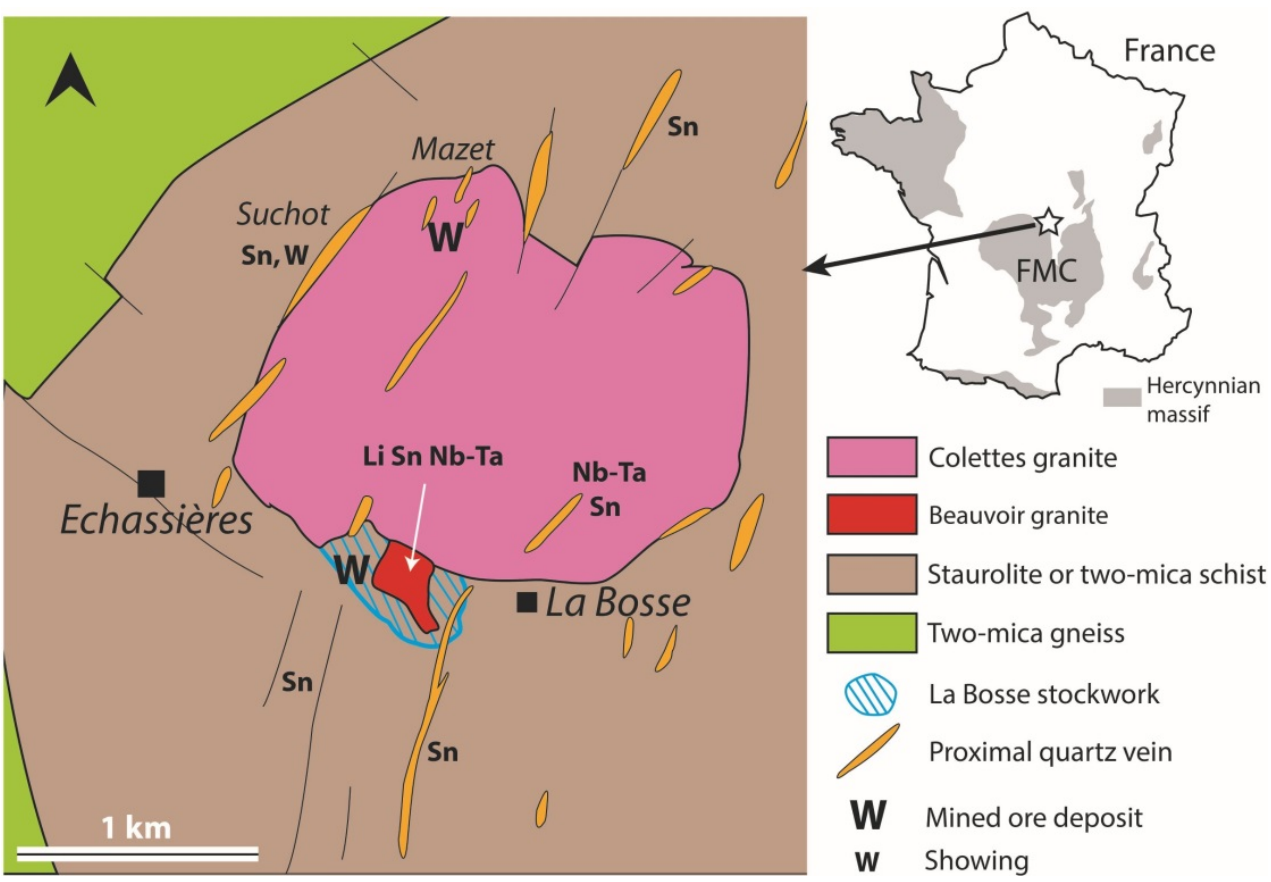

Figure 1. Geological map of the Echassières district in the French Massif Central (FMC) showing the principal mineralizations (modified after [24]). The town of Echassières is located at $46^{\circ} 11^{\prime} 01.72^{\prime \prime} \mathrm{N}$, $2^{\circ} 56^{\prime} 01.07^{\prime \prime}$ E. A schematic cross-section centered on the Beauvoir granite is available in [24].

An outstanding diversity of ore deposits is confined within a few square kilometres around the Beauvoir granite (Figure 1). These include magmatic $\mathrm{Li}-\mathrm{Nb}-\mathrm{Ta}-\mathrm{Sn}$ in the Beauvoir granite, plus $\mathrm{W}$ in a stockwork and isolated regional quartz veins, proximal and distal to the granite, that also contain $\mathrm{Sn}, \mathrm{Sb} \pm \mathrm{Nb}-\mathrm{Ta}$. The relative chronology and paragenetic sequences of these events is complex and include a number of episodes of mineralization with multiple crosscutting relationships. The first episode described in the literature is a W-bearing stockwork (La Bosse stockwork [23,25]), comprising quartz veins mineralized in ferberite (Fe-rich wolframite), which intersects, and is intersected by potassic feldspar-dominated aplitic dykes [23]. This ferberite was dated at $335 \mathrm{Ma}$ by U-Pb [7]. The second episode is related to the emplacement of the rare-metal bearing Beauvoir and the barren Colettes granites. Both plutons are identified as being younger than the La Bosse stockwork, based on crosscutting relationships. Subsequently, greisen alteration (i.e., affected both by the Beauvoir and Colettes granites), replacement of stockwork quartz by topaz (topazification) and replacement of ferberite by hubnerite (Mn-rich wolframite) was interpreted as being induced by this episode [25]. Although the absolute age of the Beauvoir granite could be better constrained ( $310 \mathrm{Ma})$, it is consistent with the field evidence for the stockwork predating the granites. The presence of hubnerite within the proximal quartz veins and of quartz and muscovite in vein halos, induced Aubert [23] and Cuney and co-authors [25] to suggest that the veins were also formed from greisen fluids, circulating in the rocks surrounding the granite. This is supported by a recent study on the trace chemistry of quartz [24], which indicates that the quartz signature of the proximal veins is statistically equivalent to that of greisen quartz, implying a likely similar source for the fluid. However, Harlaux et al. [7] assigned the same age as the stockwork ( $\sim 334 \mathrm{Ma})$ to the proximal veins most enriched in $\mathrm{W}$, the Mazet veins (exploited for hubnerite). 


\section{Materials and Methods}

\subsection{Sampling and Microscopic Investigations}

Most of the samples used in this study were collected in the field, from the Beauvoir open pit, Colettes granite, and in the Suchot area (near the town of Echassières, France). In addition, several samples representative of the different facies at depth were taken from the GPF (Deep Geology of France) drill-hole series collection (hole \# 1) (Orléans, France). Finally, samples from the Mazet wolframite mineralization were obtained from the French Geological Survey (BRGM, Orléans, France) collection, because the mine site has since been rehabilitated and does not outcrop any longer.

The mineralogy and textural relationships were investigated on polished thin and thick sections, using optical microscopy, an optical HC6-LM (Lumic, Dortmund, Germany) hot cathodoluminescence (CL) system as well as a scanning electron microscope (SEM) CL mounted on a X-five microprobe (Cameca, Gennevilliers, France). Back-scattered electron (BSE) imaging was done using a JSM 6360LV SEM (JEOL, Tokyo, Japan) equipped with a silicon-drift detector analytical system. These instruments are located at the Géosciences Environnement Toulouse (GET) laboratory (EPMA is at the Castaing Centre) in Toulouse.

\subsection{Microprobe Analysis}

The chemistry of wolframite and goethite was determined using a X-five Field Emission Gun (FEG) electron probe microanalyser (EPMA) (Cameca, Gennevilliers, France), operated with an accelerating voltage of $15 \mathrm{kV}$ and a beam current of $20 \mathrm{nA}$. For goethite, analyses were performed using a Cameca $X$-five EPMA with accelerating voltage and beam current respectively of $15 \mathrm{kV}$ and $10 \mathrm{nA}$. Both EPMA are located at the at the Castaing Centre, in Toulouse. Standardization was obtained using periclase $(\mathrm{Mg})$, wollastonite $(\mathrm{Ca}$ and $\mathrm{Si})$, corundum $(\mathrm{Al})$, pyrophanite $(\mathrm{Mn}$ and $\mathrm{Ti})$, hematite $(\mathrm{Fe})$, barite $(\mathrm{Ba})$, albite $(\mathrm{Na})$, sanidine $(\mathrm{K})$, arsenopyrite $(\mathrm{As})$, graftonite $(\mathrm{P}), \mathrm{Nb}$ metal $(\mathrm{Nb})$, Ta metal $(\mathrm{Ta}), \mathrm{W}$ metal $(\mathrm{W})$, Co metal (Co), $\mathrm{Cu}$ metal $(\mathrm{Cu})$, topaz $(\mathrm{F})$ and tugtupite $(\mathrm{Cl})$.

Table 1. Laser ablation-inductively coupled plasma-mass spectrometry (LA-ICP-MS) protocol and parameters.

\begin{tabular}{|c|c|}
\hline Laser & \\
\hline Type & CETAC Excite \\
\hline Wavelength & $193 \mathrm{~nm}$ \\
\hline Laser frequency & $8 \mathrm{~Hz}$ \\
\hline Fluence & $7 \mathrm{~J} \cdot \mathrm{cm}^{-2}$ \\
\hline Ablation spot size & $85 \mu \mathrm{m}$ \\
\hline \multicolumn{2}{|l|}{ ICP-MS } \\
\hline Model & $X$ series II \\
\hline Type & Quadrupole \\
\hline ICP RF Power & $1400 \mathrm{~W}$ \\
\hline Cooling gas (Ar) & 13 to $14 \mathrm{~L} \cdot \mathrm{min}^{-1}$ \\
\hline Carrier gas $(\mathrm{He})$ & 0.15 to $0.3 \mathrm{~L} \cdot \mathrm{min}^{-1}$ \\
\hline Auxiliary gas (Ar) & $1 \mathrm{~L} \cdot \mathrm{min}^{-1}$ \\
\hline \multicolumn{2}{|l|}{ Acquisition Parameters } \\
\hline Measured isotopes & ${ }^{7} \mathrm{Li},{ }^{9} \mathrm{Be},{ }^{11} \mathrm{~B},{ }^{23} \mathrm{Na},{ }^{27} \mathrm{Al},{ }^{29} \mathrm{Si},{ }^{47} \mathrm{Ti},{ }^{72} \mathrm{Ge},{ }^{85} \mathrm{Rb},{ }^{88} \mathrm{Sr},{ }^{93} \mathrm{Nb},{ }^{118} \mathrm{Sn},{ }^{121} \mathrm{Sb},{ }^{181} \mathrm{Ta},{ }^{182} \mathrm{~W}$ \\
\hline Dwell time per mass & $30 \mathrm{~ms}$ \\
\hline Background & $20 \mathrm{~s}$ \\
\hline Acquisition time & $40 \mathrm{~s}$ (320 pulses) \\
\hline Background collection & $20 \mathrm{~s}$ \\
\hline Wash-out delay & $20 \mathrm{~s}$ \\
\hline \multicolumn{2}{|l|}{ Data Reduction } \\
\hline Software & Glitter ${ }^{\circledR}$ \\
\hline Standard & NIST SRM 612 [38] \\
\hline
\end{tabular}




\subsection{Laser Ablation-Inductively Coupled Plasma-Mass Spectrometry (LA-ICP-MS) Analysis}

Laser ablation-inductively coupled plasma-mass spectrometry (LA-ICP-MS) (Laser: Teledyne CETAC, Omaha, NE, USA; ICP-MS: Thermo Fisher Scientific, Waltham, MA, USA) was used to analyse the trace element content in topaz, at the BRGM facilities (Orléans, France). The analytical protocol and treatment of the acquired spectra are strictly the same as those used for quartz analysis by Monnier et al. [24], thus only a summary of the protocol is provided here (Table 1), while the reader is invited to consult the above reference for exhaustive details. The amounts of $\mathrm{SiO}_{2}$ (internal standard) in topaz were measured using the Castaing Centre EPMA (see above). The $\mathrm{SiO}_{2}$ amount remained constant for all topaz types with values equal to c.a. $32 \mathrm{wt} . \%$.

\section{Petrography}

\subsection{Beauvoir and Colettes Granites}

The Colettes intrusion consists of a two-mica porphyritic granite. Alkali feldspar, and, less commonly, quartz and plagioclase form the phenocrysts (currently 0.5 to $2 \mathrm{~cm}$ in size). Cordierite, although not ubiquitous, is a relatively common phenocryst. The phaneritic groundmass consists of muscovite, biotite and quartz.

The Beauvoir granite consists mostly of an equigranular variety, which is made up essentially of albite, quartz and lepidolite, with subordinate amounts of potassic feldspar and topaz. This granite is particularly known as an "exotic mineral" carrier (in order of decreasing occurrence): cassiterite, columbite-group minerals, pyrochlore, zircon. The occurrence of amblygonite has been reported [23,25]. More details on its igneous paragenesis (e.g., minor facies, textures and chemistry of secondary minerals, mineral paragenesis) can be found in [23-26,31,39].

Greisen alteration affected both the Beauvoir and Colettes granites, in particular the apical parts of the former. This alteration is marked by pervasive dissolution of primary magmatic minerals. Feldspar, and cassiterite at Beauvoir (Figure 2A), are particularly affected, although all primary minerals may be attained to various degrees. Secondary phases include green to golden yellow muscovite, which can form pseudomorphs after primary mica (Figure 2B), hydrothermal quartz (Figure 2C,D), commonly observed in association with colourless to deep blue apatite (Figure 2E-I) that is zoned with respect to $\mathrm{Sr}$ contents (visible in EDS SEM imaging; Figure $2 \mathrm{H}$ ). Locally, the rock is entirely sericitized. The characteristics of the greisen alteration are identical for the two granites, except for the presence of W-rich rutile at Colettes (Figure 2I) and of hydrothermal pyrochlore and colombite-group minerals in the Beauvoir granite (Figure $2 \mathrm{~F}, \mathrm{H}$ ). In addition to being affected by pervasive alteration, both granites are crosscut by sub-vertical veins made up entirely of quartz and exhibiting strongly geisenized selvages (quartz + muscovite).

Late, massive kaolinization affected parts of the granites that had been previously strongly geisenized. This alteration caused a significant increase in the porosity of the rock (Figure 3A-C). Here, greisen-stage muscovite is partially to completely replaced by kaolinite (Figure 3A,B), and apatite systematically shows signs of alteration, even where muscovite is preserved from kaolinization (Figure 3C). Accessory minerals that are part of the alteration assemblage are Mn-oxydes, W-rich goethite and gorceixite-goyazite solid solution (Figure 3D,E). These minerals, plus quartz, are also found in late, brecciated veins that show evidence of multiple reactivation episodes underlined by several generations of quartz (Figure 3F). 

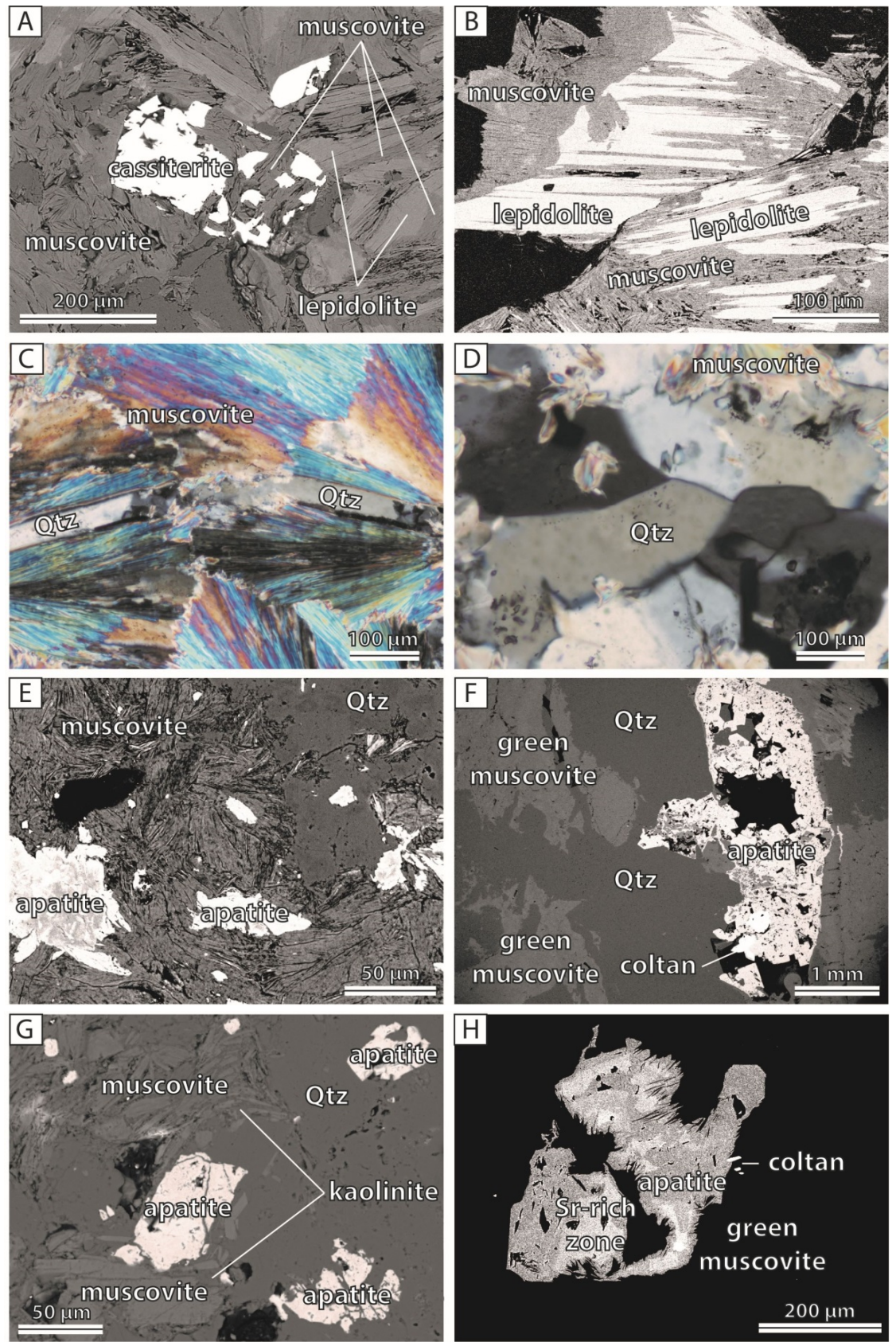

Figure 2. Cont. 

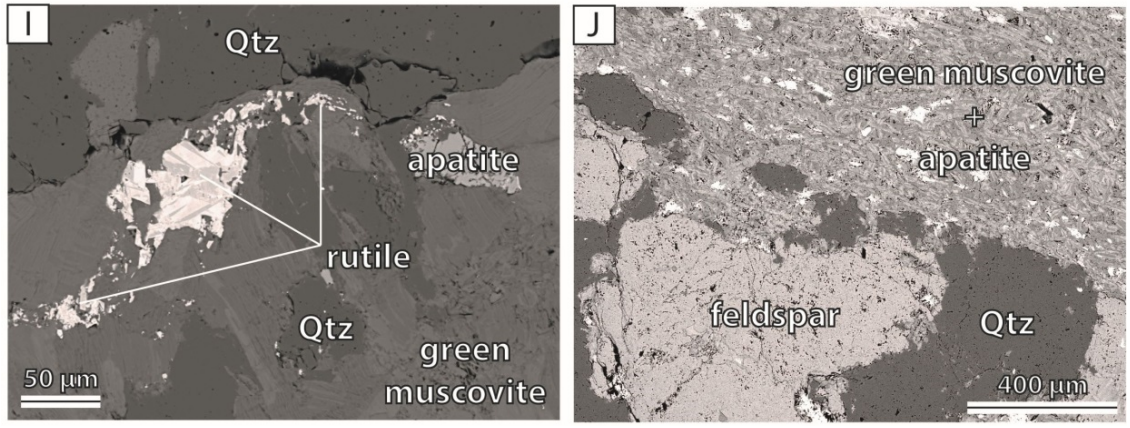

Figure 2. Photomicrographs illustrating greisen assemblage in Beauvoir (images $\mathbf{A}$ to $\mathbf{H}$ ) and Colettes (images I and J) granites. (A) Backscatter electron (BSE) image of igneous lepidolite and cassiterite partially replaced by hydrothermal muscovite. (B) Lepidolite partially replaced by muscovite (BSE). (C) Crossed-polarized light (XPL) image of hydrothermal quartz crystalized along muscovite cleavage direction. (D) Inclusion of muscovite in hydrothermal quartz (XPL). (E-G) Images of the three principal greisen minerals, i.e., quartz, muscovite and apatite, and their textural relationships in several parts of strongly altered Beauvoir granite (BSE). (H) An apatite crystal surrounded by muscovite, displaying $\mathrm{Sr}$ zoning, visible by light and darker BSE shades. (I) Hydrothermal apatite, rutile, muscovite and quartz in geisenized Colettes granite. Quartz in the upper part of the image is a relic of the igneous generation (BSE). (J) Hydrothermal muscovite and apatite altering igneous quartz and potassic feldspar relicts (BSE). Coltan $=$ colombo-tantalite.
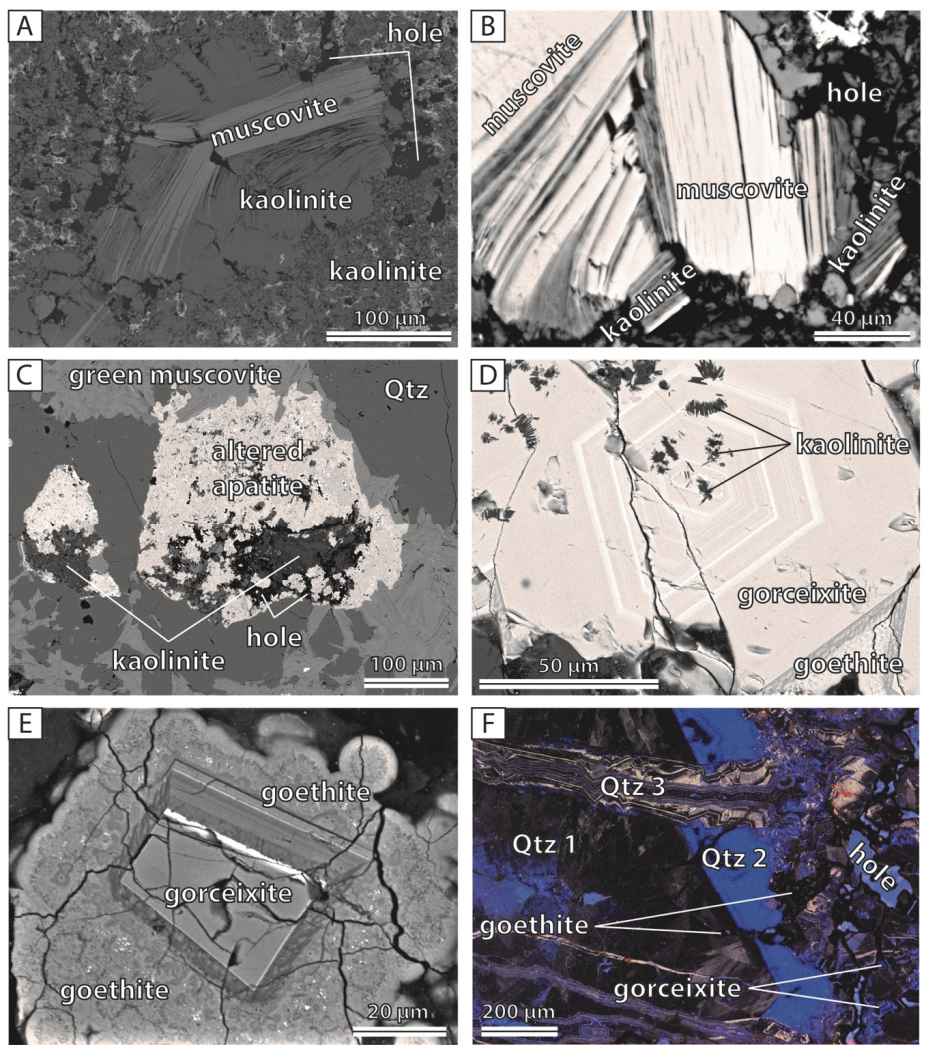

Figure 3. Photomicrographs illustrating the kaolinization assemblage in the Beauvoir granite (A to C) and in late quartz veins within (D to F). (A), (B): BSE images showing partial pseudomorphs of kaolinite after greisen muscovite. (C): Partial alteration of apatite by kaolinite (BSE). (D): Small kaolinite inclusions in a well-zoned gorceixite crystal. (E): A gorceixite crystal overgrown by botryoidal goethite (BSE). (F): A cathodoluminescence (CL) image showing three quartz generation plus minor goethite, gorceixite and quartz, in a breccia zone. 


\subsection{La Bosse Stockwork Area}

The La Bosse stockwork consists of a network of quartz veins and dykes intruded in PAU schist. Potassic feldspar-dominated aplite dykes are contemporaneous with the stockwork [23]. Another generation consists of leucocratic albite-dominated (albitite) dykes, showing the same facies as the Beauvoir granite and crosscutting all other lithologies.

\subsubsection{Quartz Veins}

The La Bosse stockwork consists of a network of quartz veins of varied geometry. Most of them are subhorizontal, about $10 \mathrm{~cm}$ in width, and strike parallel to the schistosity. Quartz in the veins is fine- to medium-grained (100 $\mu \mathrm{m}$ to $5 \mathrm{~mm})$ and, invariably, shows evidence of recrystallization of the grain-boundary migration (GBM) type, suggesting ductile deformation. Wolframite occurs in some of these veins, particularly in the smaller ones. In veins that are not attained by further alteration, wolframite forms clusters of anhedral to subhedral fine-grained crystals, and show evidence of partial corrosion (Figure $4 \mathrm{~A}, \mathrm{~B})$. These wolframites are characterized by inclusions of russellite $\left(\mathrm{Bi}_{2} \mathrm{WO}_{6}\right)$ and native bismuth (Figure $4 \mathrm{C}$ ), tourmaline, ilmenite, rutile, cassiterite. Although some of these minerals may also be hosted by quartz, they are always found in the immediate vicinity of wolframite. This occurrence of wolframite is herein named wolframite $a$.
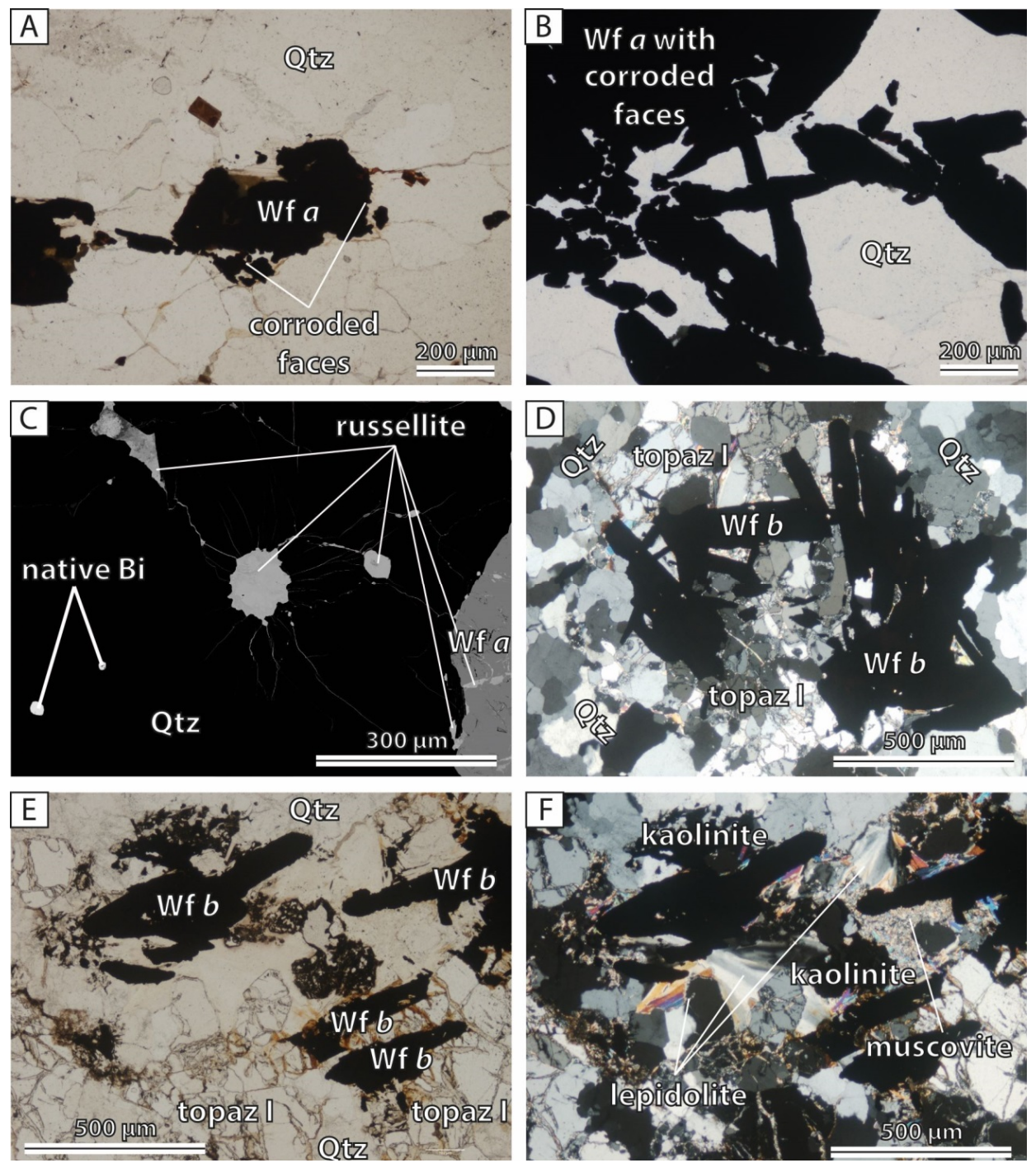

Figure 4. Cont. 

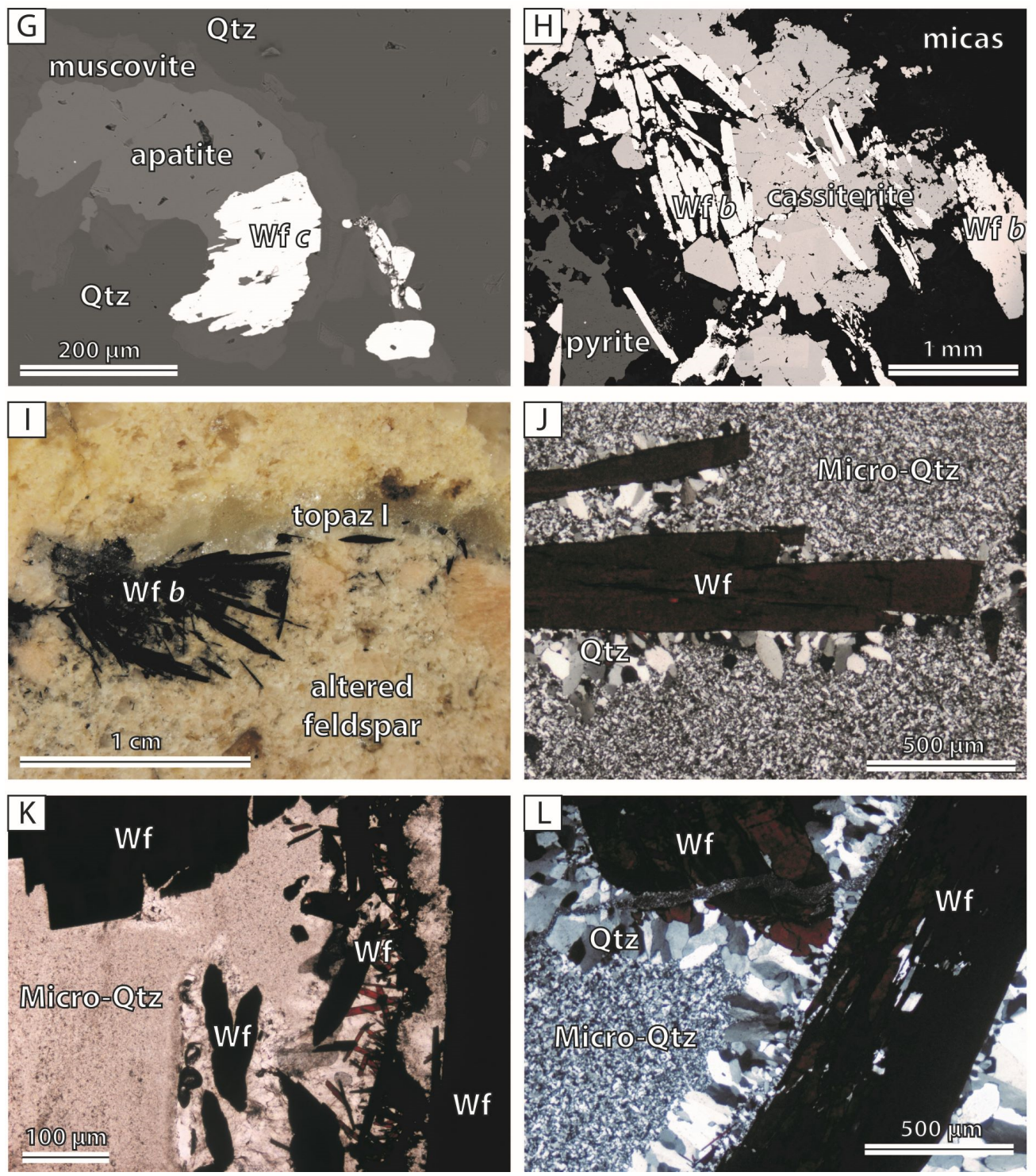

Figure 4. Photomicrographs illustrating habits of wolframite occurrences in the Echassières district: quartz vein of la Bosse stockwork (A to $\mathbf{G})$; altered schist in the stockwork area (H); altered aplitic dike of la Bosse Porphyry (I); and Mazet veins (J to L). (A), (B): Plane-polarized light (PPL) images of wolframite $a$ crystals exhibiting corroded faces. Smaller wolframite grains may occur as inclusion in quartz recrystallized by grain-boundary migration (GBM). (C): Bismuth bearing minerals (russellite and Bi metal) associated to wolframite $a$. (D): XPL image of a small pocket in a quartz vein filled with wolframite $b$, topaz and scarce lepidolite (birefringent mineral). (E), (F): Same image viewed in PPL and $\mathrm{XPL}$, respectively. Wolframite $b$ plus topaz and fans of lepidolite in a quartz vein. Lepidolite and topaz are altered to greisen muscovite, itself partially altered by kaolinite. (G): Wolframite $c$ accompanied by greisen minerals apatite and muscovite, within a fracture in a quartz vein. $(\mathbf{H})$ : Rods of wolframite $b$ associated with anhedral cassiterite and pyrite, in altered schist (BSE). (I): Wolframite $b$ and topaz in altered potassic feldspar crystals (binocular microscope view of a polished sample). (J) to (L): Rods of wolframite $c$ in a microquartz groundmass (Mazet vein). Well crystallized quartz grows on some wolframite faces, perpendicularly to them. Images were taken in XPL ( $\mathbf{J}$ and $\mathbf{L})$ and PPL $(\mathbf{K})$.

Several of these veins have undergone topazification locally to quite an intensive manner along intervals of several meters in length. Here, quartz is replaced by green topaz, accompanied by lower amounts of mica (F-rich biotite to lepidolite solid solution; Figure 4E,F). Abundant wolframite, associated with this topazification forms large euhedral, pristine crystals ( $\mathrm{mm}$ to $\mathrm{cm}$ in size), which are 
markedly different from the wolframite $a$, described above; we thus named it wolframite $b$ (Figure 4D-F). This wolframite type may be associated to subordinate amounts of cassiterite. Although wolframite $b$ commonly occurs with topaz, locally it may be observed surrounded by quartz, similarly to wolframite a. Nevertheless, different textural relationships with quartz permit us to distinguish it from wolframite a. Quartz at the contact with wolframite b, may display deformation textures (fracturing to bulging and sub-grain rotation ductile recrystallization; Figure 5A,L), evidence of hydrothermal recrystallization (undiscernible in XPL but visible in cathodoluminescence; Figure 5E,I-L), contains secondary mica veinlets and fluid inclusion trails (Figure 5A-D,G,H). All of these features are generally connected in space, forming a network that marks the pathways that were taken by the fluid during topazification. Crystals of wolframite $b$ occur in these alteration areas, with small crystals commonly aligned in the fine recrystallized channel pathways (Figure 5F). These alteration networks obviously record fluid circulation that postdated both formation of quartz and its early recrystallization by GBM.
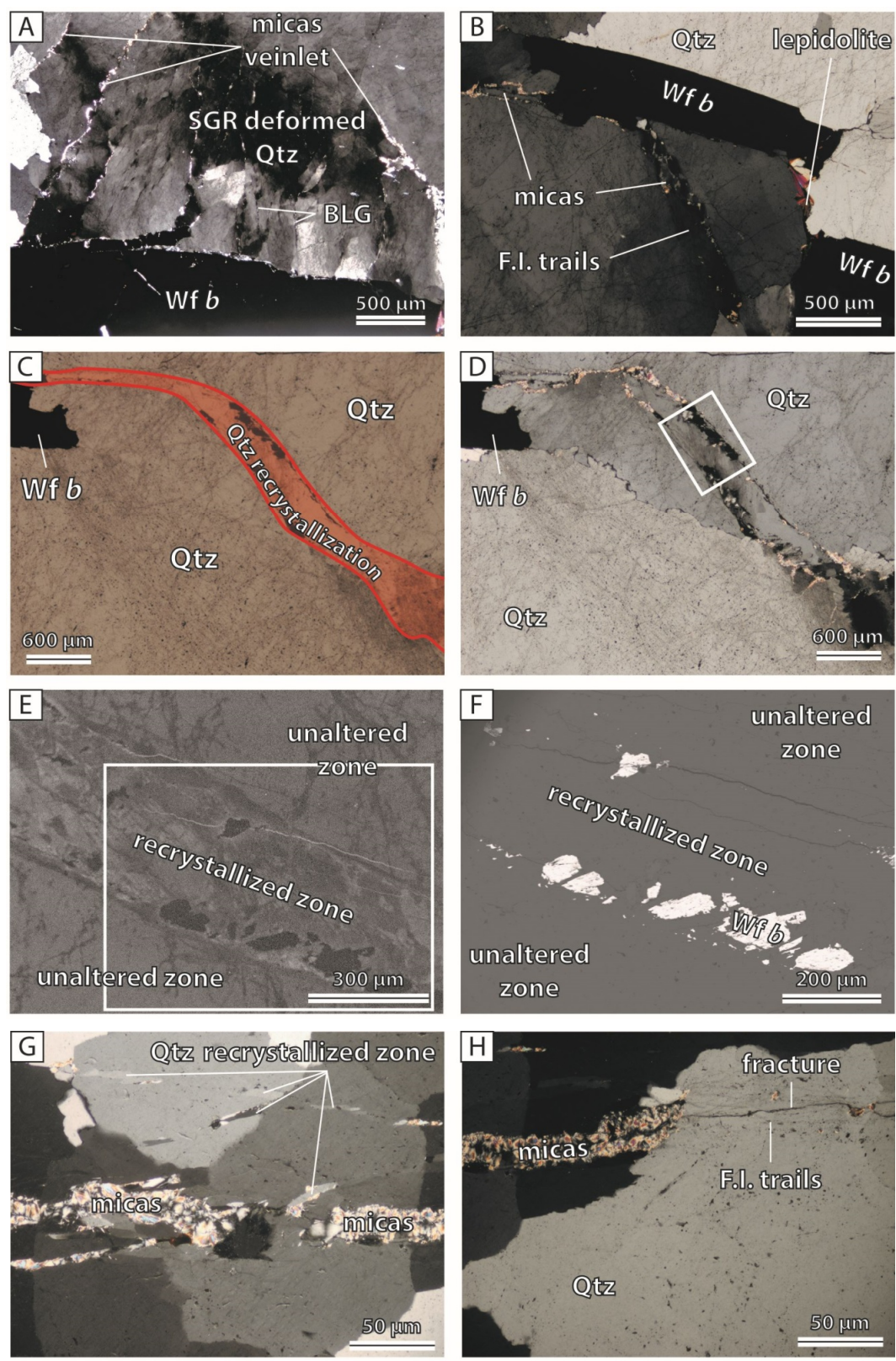

Figure 5. Cont. 

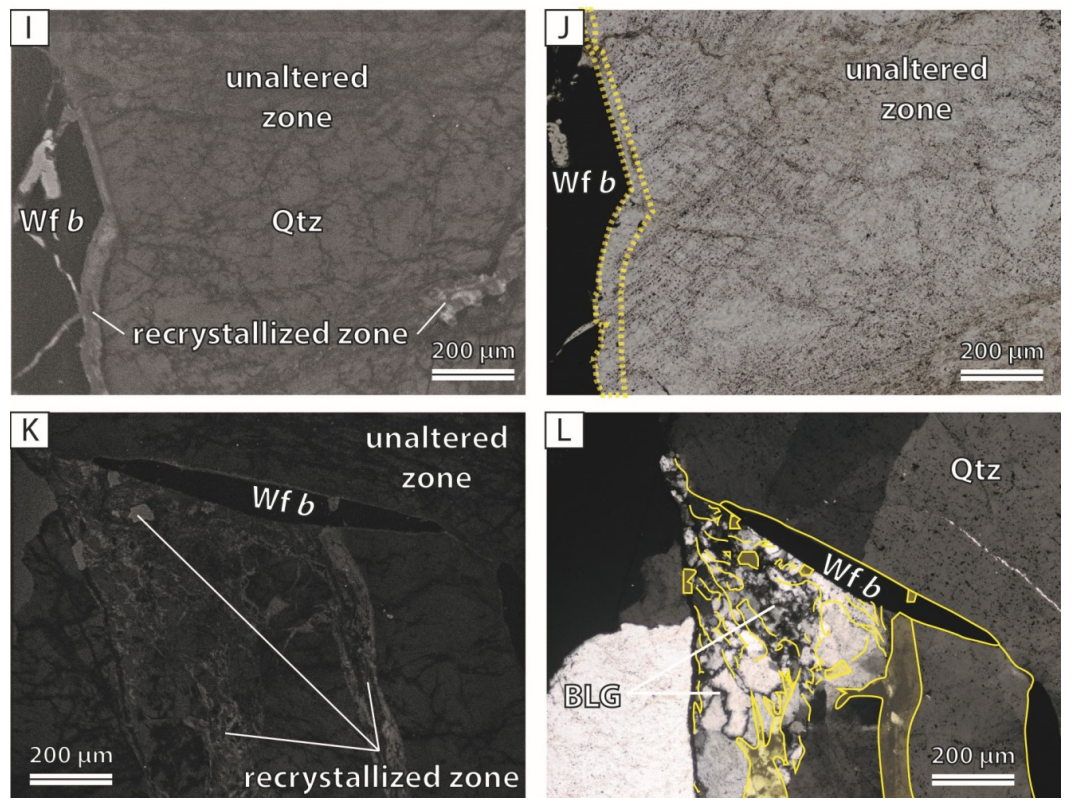

Figure 5. Photomicrographs illustrating the textural relationship between wolframite $b$ and the host quartz in the La Bosse stockwork. (A): XPL image of brittle and ductile deformation next to wolframite (SGR: SubGrain Rotation; BLG: BuLGing). (B): wolframite $b$ crystals localized at the boundary of quartz grain, linked by bands of fluid inclusions (FI) trails and micas (XPL). (C), (D): PPL and XPL images, respectively, showing bands defined by fluid inclusion trails and micas (outlined in red in C). (E): Details of the area outlined in D. Scanning electron micrograph (SEM) CL showing a recrystallized quartz zone (dark grey) at the interior of a band defined by fluid inclusion trails and micas. (F): BSE image of the area outlined in E showing small wolframite $b$ crystals in the recrystallized quartz zone. $(\mathbf{G}),(\mathrm{H})$ : details of quartz grains intersected by bands defined by fluid inclusion trails and micas. Micro-fracturing in quartz and fluid inclusion trails mark the continuation of the mica veinlets, more or less evidently (XPL). (I), (J): Respectively, SEM-CL and XPL images of recrystallized quartz in contact with wolframite b. (K), (L): Respectively, SEM-CL and XPL images of interlocking BLG and hydrothermal (yellow lining in $\mathbf{L}$ ) recrystallization of quartz next to a wolframite $b$ rod.

The quartz veins may also be affected by greisen alteration, although much less intensively than they are by the topazification. Indeed, only the veins in the immediate vicinity (less than one meter) of the Beauvoir granite's roof are affected, such as those forming enclaves inside the granite. In addition, primary minerals are only slightly altered, and most evidence for this alteration is the precipitation of small crystals of muscovite (Figure $4 \mathrm{E}, \mathrm{F}$ ) and apatite within strongly fractured zones of the vein. In places, small rods of wolframite, measuring less than 200 microns, accompany the greisen minerals (Figure 4G). We name this generation wolframite $c$.

Contrary to greisen alteration, evidence for kaolinization is common in the quartz veins, with replacement of micas by kaolinite and, more rarely, addition of gorceixite (Figure 6A). Moreover, 5 to 10 percent of wolframite $a$ and $b$ crystals were partially or totally replaced by W-rich goethite and kaolinite (Figure 6B-D). 

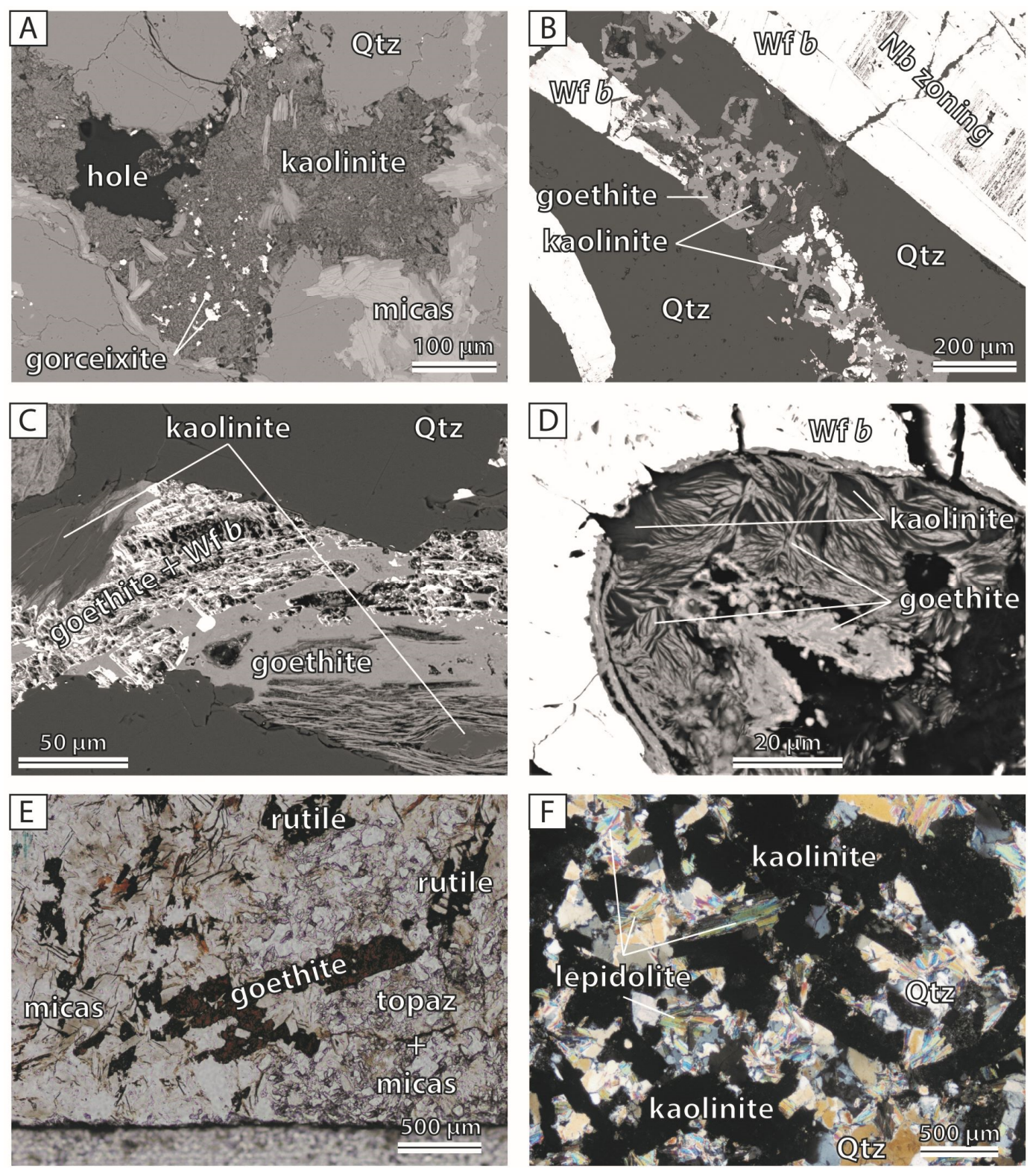

Figure 6. Photomicrographs illustrating the kaolinization assemblage in the La Bosse Stockwork quartz veins (A to D), metasomatized schist (E) and Beauvoir albitite dyke (F). (A): Kaolinite, with gorceixite, fills the porosity in a quartz vein (BSE). (B)-(D): Images at different scales illustrating gosts of wolframite $b$ filled by goethite and kaolinite (BSE). (E): Goethite replacing wolframite $b$; other minerals are unaffected (PPL). (F): Contrary to the Beauvoir main body, Beauvoir dykes commonly display kaolinite alteration without evidence of greisen alteration. Here, alkali feldspars are altered to kaolinite, which takes a rectangular shape (XPL; note, slightly thick section).

\subsubsection{Topaz Veins}

Topaz veins crosscut the quartz veins and show identical mineralogy to the topazified quartz veins, i.e., topaz, F-rich biotite to lepidolite micas series, wolframite $b$. Locally, these micas show evidence of later replacement by green or golden yellow muscovite (Figure 7C). Also, some topaz veins were reactivated, with precipitation of a second topaz generation accompanied by cassiterite (Figure 7D). The two topaz generations are, therefore, called "topaz I" and "topaz II". At the end of topaz vein reactivation, quartz crystallized locally, texturally postdating the topaz II generation (Figure 7A,B). 

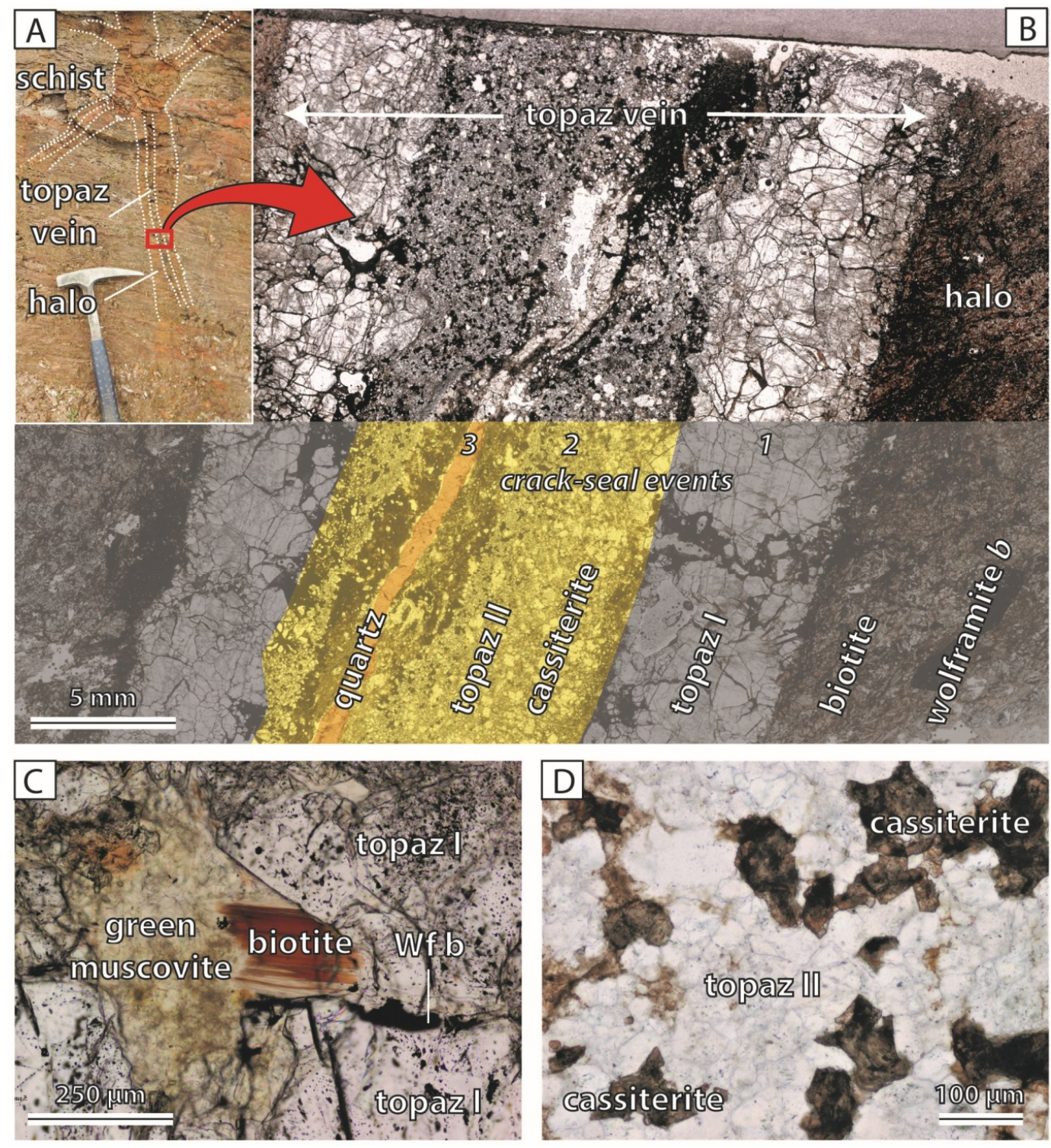

Figure 7. Photomicrographs showing textural details a topaz vein (outcrop image in (A)), from the La Bosse stockwork. (B): A high resolution scan of a whole thin section, showing multiple crack-seal events in the vein (events and minerals filling the vein are labelled in the false-colored bottom half of the image). (C): The first crack-seal event corresponds to the topaz-I generation, with precipitation of scarce wolframite $b$ and biotite, partially altered to green muscovite (PPL). (D): The second crack-seal event is characterized by precipitation of topaz II and important amounts of cassiterite (PPL).

\subsubsection{Schist Host Rock}

Unaltered schist consists of quartz, muscovite, biotite and, less commonly, staurolite and garnet (Figure 8A,B. In the stockwork area, close to quartz veins, ilmenite and tourmaline become abundant, which is unexpected for metamorphic rocks. Both minerals display the same geometry and texture, i.e., they form rods of 5 to $600 \mu \mathrm{m}$ in length that are included in the metamorphic minerals, either randomly oriented (e.g., in garnet and staurolite; Figure 8B,D,F) or parallel to the schistosity (e.g., in mica; Figure $8 \mathrm{C}, \mathrm{E}$ ). Schist that is cut by topaz veins is strongly metasomatized along the vein selvages. Metamorphic micas are replaced by F-rich biotite, topaz, rutile, and wolframite $b$, which in altered schist is generally pseudomorphosed by goethite (Figure 6F). Locally, tiny veinlets consisting of mica, wolframite $b$, cassiterite and pyrite intersect the schist. These veinlets do not contain quartz nor topaz. 

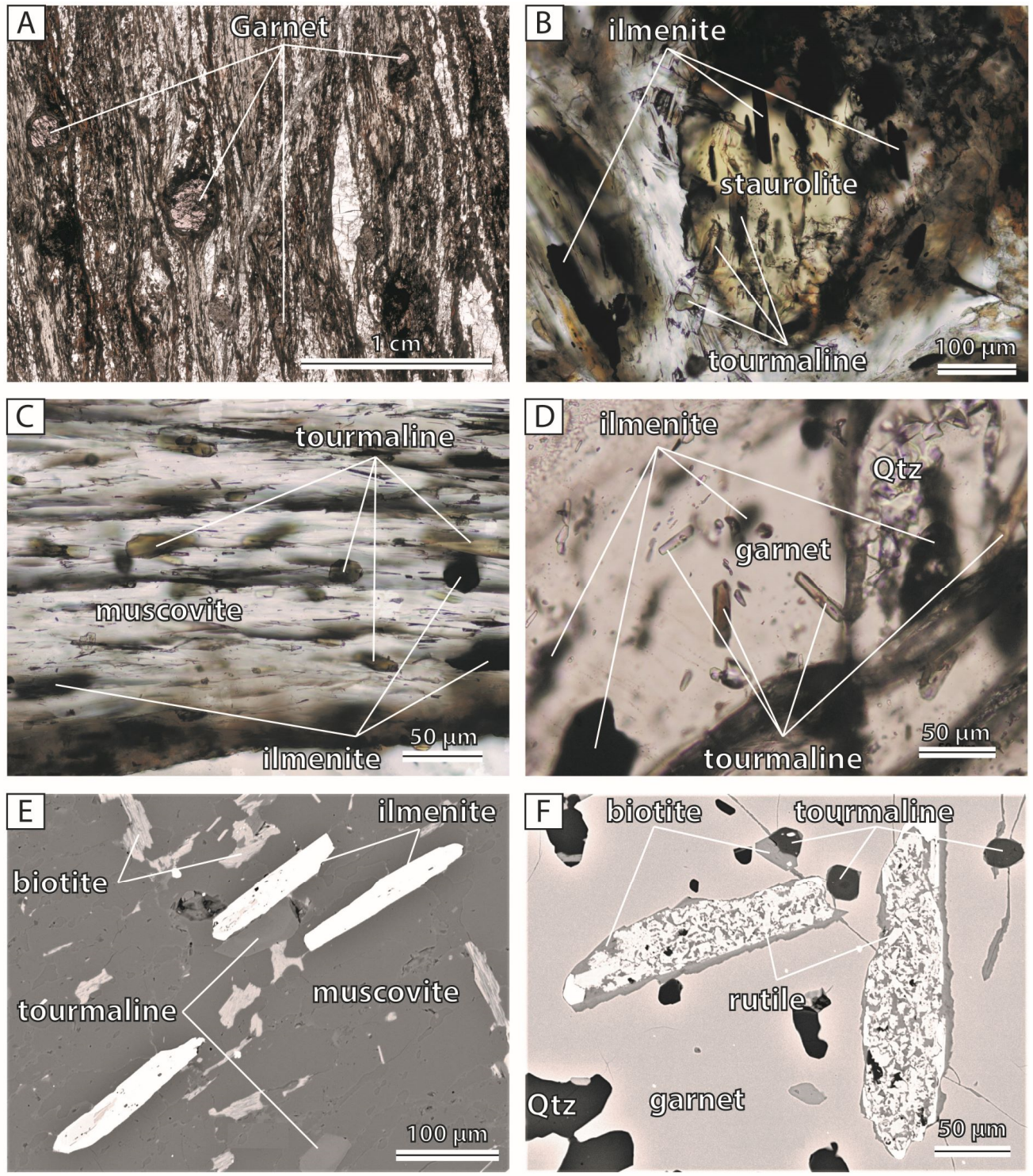

Figure 8. Photomicrographs illustrating the metamorphic assemblage in the La Bosse stockwork host rock. (A): texture of the schist host rock (thick section high resolution scanning). (B): Tourmaline and ilmenite inclusions in staurolite (PPL). (C): Muscovite in schist containing inclusions of ilmenite and tourmaline rods, oriented parallel to its cleavage (PPL). (D): details of a garnet porphyroblast showing inclusions of randomly oriented tourmaline and ilmenite crystals (PPL). (E), (F): BSE images of ilmenite and tourmaline occurring as inclusions in muscovite (plus minor biotite) (E) and garnet (F). lmenite in garnet shows strong alteration to rutile plus biotite.

Although aplitic potassic feldspar-dominated dykes and albitite dykes of Beauvoir facies are not characterized in this study, it is important to mention that topazification affected the former, with co-precipitation of wolframite $b$ (Figure $4 \mathrm{I}$ ), whereas the Beauvoir dykes underwent only minor greisen alteration plus widespread kaolinite alteration (Figure $6 \mathrm{~F}$ ).

\subsection{Proximal Veins}

A number of quartz veins occur near the Colettes and Beauvoir granites and in places intersect these plutons. They are mostly oriented NNE-SSW with subvertical dips and may carry W mineralization. For this study, we selected two representative examples: The Suchot vein, which contains minor 
cassiterite and W-bearing rutile in its halos, and the Mazet veins, which host important amounts of wolframite (cf., Figure 1 for location).

The Suchot vein is composed mostly of large euhedral quartz crystals (up to cm size), commonly overgrown by fibrous quartz (Figure 9A). Layers in the vein may contain muscovite with a microcrystalline texture (sericite; Figure $9 \mathrm{~B}$ ) similar to the texture shown by the Beauvoir greisen. The Suchot vein is affected by late thin fractures, sealed by goethite and kaolinite. The vein selvages are strongly altered by a complex assemblage including several generations of micas, quartz and accessory W-rich rutile, monazite and xenotime, locally resembling the greisen texture (Figure 9C). In the host schist, minor quartz veins are crosscut by the Suchot vein. In these early veins, tourmaline can occur in important amounts in form of inclusions in GBM deformed quartz, similar to the ilmenite and tourmaline inclusions in the metamorphic minerals described above (Figure 9D).
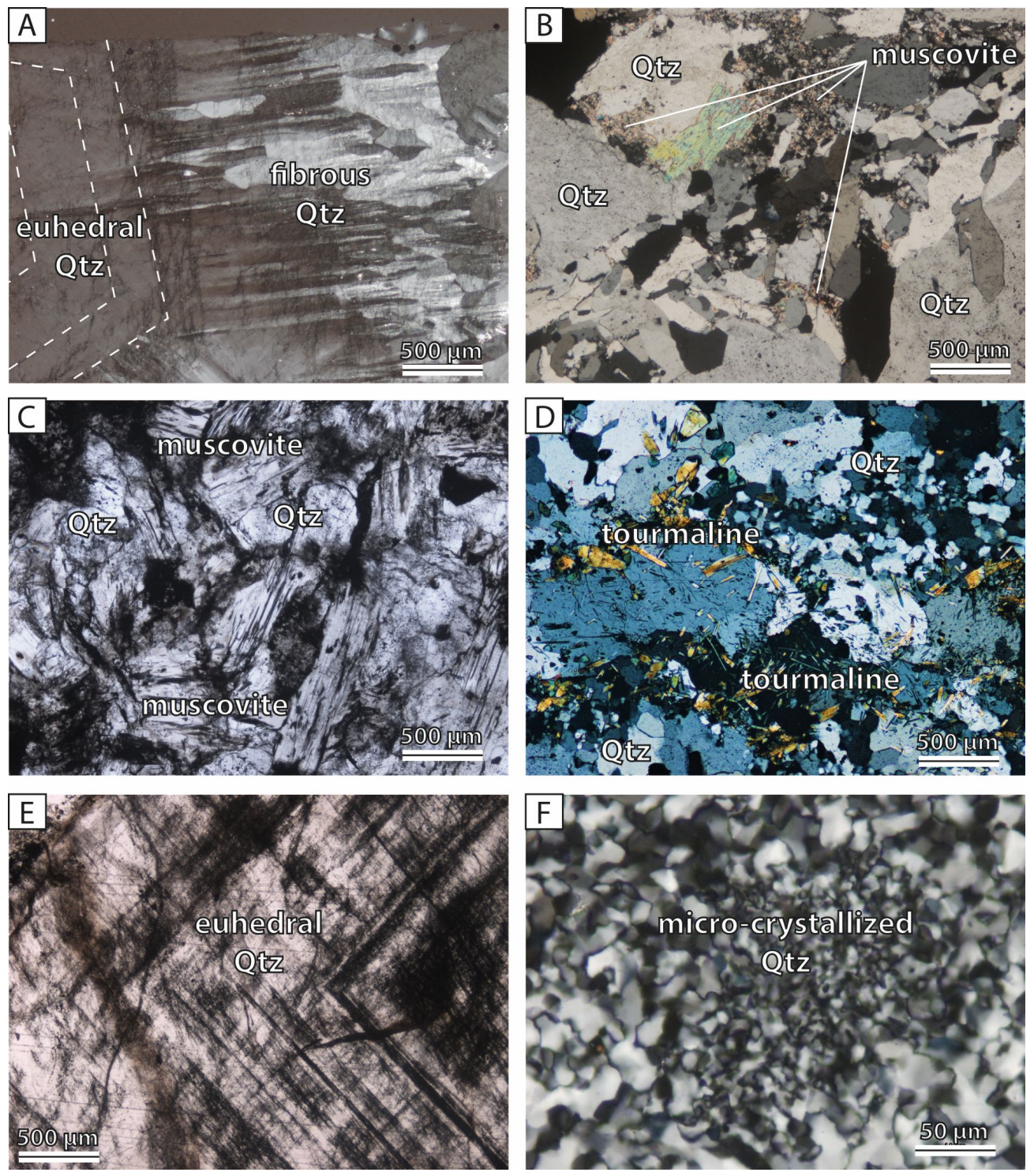

Figure 9. Photomicrographs illustrating quartz textures in the proximal Suchot vein (A to B) and its host rock (C and D), and in the proximal Mazet veins (E and F). (A): At Suchot, quartz commonly displays a euhedral core with fibrous overgrowth (XPL). (B): A layer in the vein showing well-crystallized muscovite and sericite (XPL). (C): In the selvage of the quartz vein, muscovite and quartz have entirely replaced the metamorphic minerals (PPL). (D): Detail of a quartz-tourmaline vein that is crosscut by the Suchot vein. Quartz in this vein is recrystallized by GBM (XPL). (E), (F): First-generation cm-sized euhedral quartz (E) and poorly-crystallized second-generation quartz at Mazet (F) (XPL). 
The Mazet veins contain two generation of quartz: the earliest consists of euhedral grains of up to a few $\mathrm{cm}$ in size, with well-formed growth zones marked by primary fluid-inclusion (Figure 9E). The second generation consists of poorly-crystallized anhedral micro-quartz ( 5 to $50 \mu \mathrm{m}$ in size) that does not contain fluid inclusions (Figure 9F). Aubert [23] describes the presence of strong greisen alteration in the host rock immediately adjacent to the veins. Wolframite occurs within the second quartz generation (Figure 4J-L) where it forms euhedral rods of various lengths (ca. $20 \mu \mathrm{m}$ to $2 \mathrm{~cm}$ ) that are reddish in colour, similarly to the wolframite $c$ recognized in the greisen. However, because these wolframites occur in very different textural contexts, mineral analyses will be necessary to corroborate their affinity.

\section{Mineral Chemistry}

EPMA and LA-ICP-MS analyses were performed on wolframite, goethite and topaz from a large number of samples covering the rocks from the Echassières complex described above. A complete list of results is given in the Supplementary Material (Table S1), whereas the most significant data are depicted in several diagrams, herein.

\subsection{Wolframite}

Respectively 4, 8 and 1 samples of wolframite $a, b$ and $c$, as well as 2 mineralized samples from the Mazet veins, were selected for EPMA analyses, for a total of more than 800 analyses on about 100 wolframite crystals. The $\mathrm{FeO} / \mathrm{MnO}$ ratios highlight three populations (Figure 10), corresponding to (in order of increasing value): a group consisting of wolframite $c$ and wolframite from the Mazet veins $(\mathrm{FeO} / \mathrm{MnO}$ ratio $=0.3)$; a second group corresponding to wolframite $b(\mathrm{FeO} / \mathrm{MnO}$ ratio $=3.5)$; and a last group consisting of wolframite $a(\mathrm{FeO} / \mathrm{MnO}$ ratio $=8.4)$. For each group, the data distribution is statistically normal, with $50 \%$ of the values occurring very close to the median value. The amount of $\mathrm{Nb}_{2} \mathrm{O}_{5}$ varies within each of the three groups; most of the values for the Mazet vein data are below the maximum detection limits $(0.12 \mathrm{wt} . \%)$, while for wolframite $a$ and $b$ they mostly exceed detection limits, with the latter commonly greater than $1 \mathrm{wt} . \%$. Interestingly, wolframite $b$ is zoned with respect to $\mathrm{Nb}$ (Figure 6b; see also [40] Figure 2).
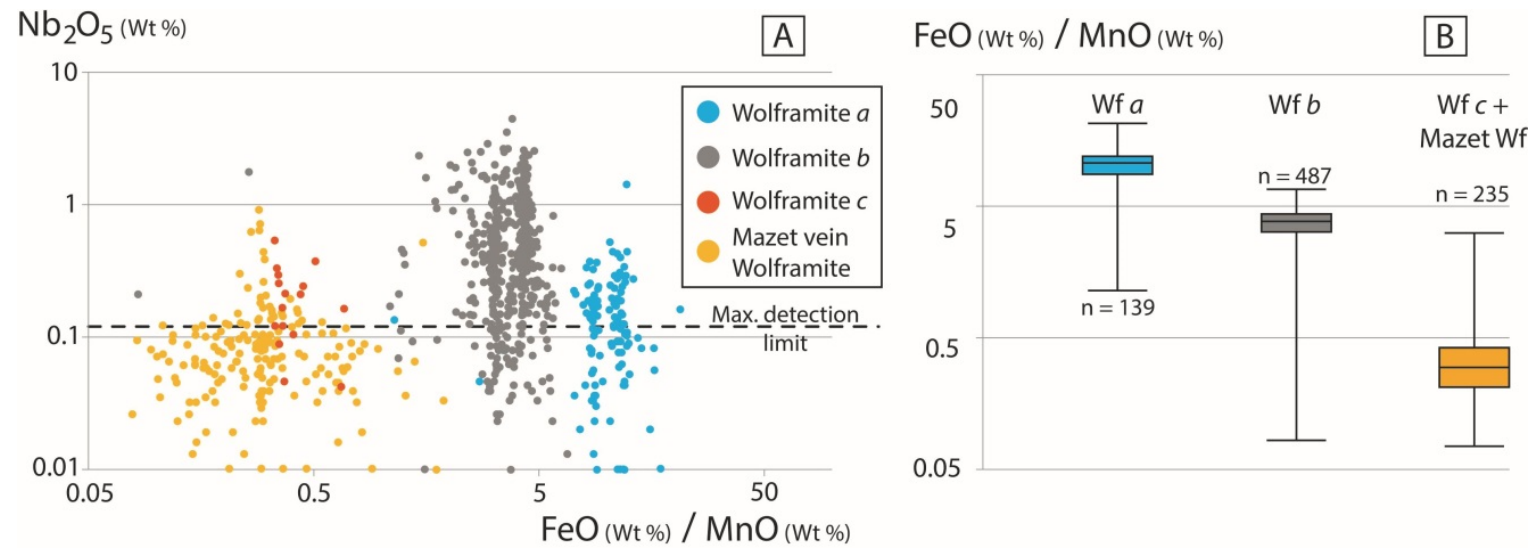

Figure 10. Compilation of all wolframite electron probe microanalyser (EPMA) data highlighting three distinct regions in $\mathrm{FeO} / \mathrm{MnO}$ space ( $\mathbf{A}$ and $\mathbf{B}$ ) and a spread in $\mathrm{Nb}$ content as a function of this ratio (A). Boxplots illustrate the minimum, maximum, and three quartile values for each wolframite group (B). The detection limit shown in (A) corresponds to maximal values.

\subsection{Goethite}

Goethite, or more strictly, W-rich ferric iron oxide material for the most W-enriched [41], contains a variable amount of $\mathrm{W}$ (32 analyses in 5 samples), as well as $\mathrm{Al}$ and $\mathrm{P}$ (Figure 11). When replacing wolframite in schist, goethite has up to $20 \mathrm{wt} . \% \mathrm{WO}_{3}$; in this case the mineral could not be unequivocally 
identified, as goethite crystallographic features are perturbed by the high $\mathrm{W}$ content [42]. Where goethite crystallizes in the vicinity of W-mineralization, as is the case in the stockwork area or in the Suchot vein where it is associated with wolframite and W-rich rutile, respectively, it contains intermediate amounts of $\mathrm{WO}_{3}(2-7 \mathrm{wt} . \%)$. Finally, in areas without $\mathrm{W}$-mineralization, like in the late quartz veins within the Beauvoir granite (Figure 3), $\mathrm{WO}_{3}$ concentrations in goethite are very low ( $<1$ wt.\%). $\mathrm{P}_{2} \mathrm{O}_{5}$ and $\mathrm{Al}_{2} \mathrm{O}_{3}$ concentrations show high variability, with the lowest values occurring in the goethite from the Suchot vein. Noteworthy, most EPMA analyses of goethite display quite low totals, suggesting a larger contribution of $\mathrm{OH}$ and/or $\mathrm{H}_{2} \mathrm{O}$ than expected, according to Keissl et al. [42], or the presence of small amounts of other elements that were not detected or not analyzed.
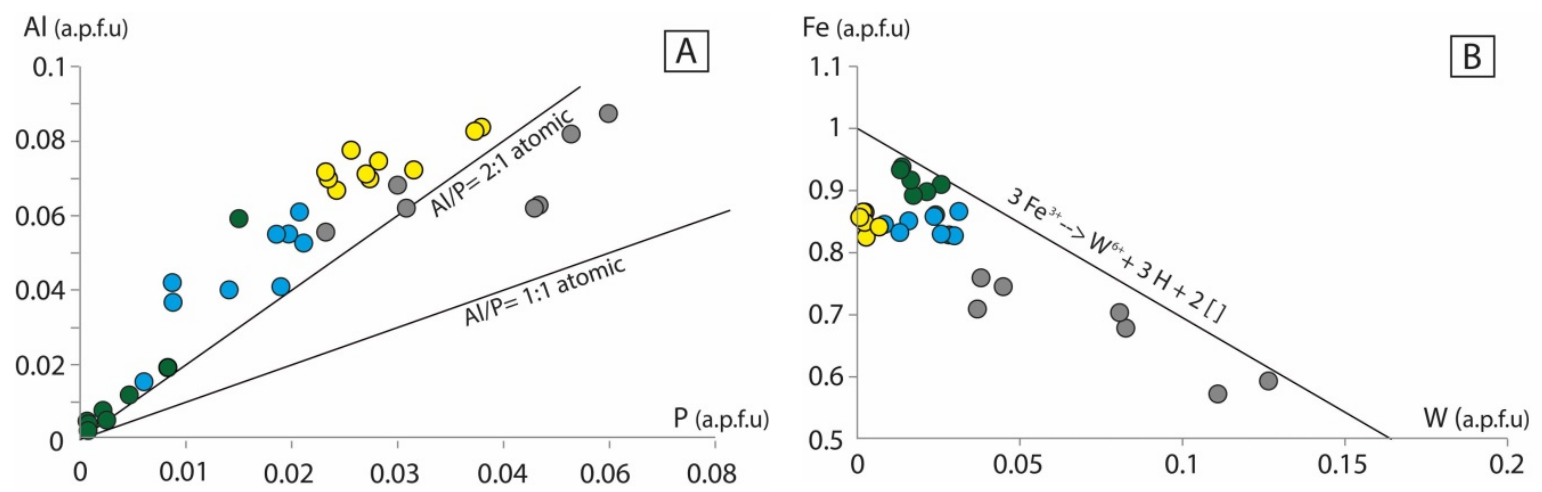

$$
\begin{aligned}
& \text { late quartz vein (Beauvoir) } \\
& \text { pseudomorph after Wf } b \text { in schist } \\
& \text { veinlet in stockwork quartz vein } \\
& \text { veinlet in Suchot quartz vein }
\end{aligned}
$$

Figure 11. EPMA data for goethite; binary diagrams show positive correlations for $\mathrm{Al}$ and $\mathrm{P}(\mathbf{A})$, and negative correlations for Fe and W (B). Values are in atoms per formula units (a.p.f.u.) and the equation used for W substitution for Fe is that of [42].

\subsection{Topaz}

The two types of topaz are indistinguishable based on their EPMA data, with $\mathrm{F}$ varying from 19 to $21 \mathrm{wt}$.\% for both types. Among all elements analysed by LA-ICP-MS in topaz ( $\mathrm{Li}, \mathrm{Be}, \mathrm{B}, \mathrm{Na}, \mathrm{Al}, \mathrm{Ti}$, $\mathrm{Ge}, \mathrm{Rb}, \mathrm{Sr}, \mathrm{Nb}, \mathrm{Sn}, \mathrm{Sb}, \mathrm{Ta}, \mathrm{W}$ ), only Ti and Ge were detected in all samples (6 samples for 55 analyses), where they can show values greater than $100 \mathrm{ppm}$. The amount of Ge remains approximately constant in the different topaz types, while topaz from La Bosse stockwork, with the exception of topaz II in the polyphased vein, contains more Ti than igneous topaz from Beauvoir (Figure 12a). Other elements, such as $\mathrm{Li}, \mathrm{W}$ and $\mathrm{Ta}$, vary in the different types, although they remain below detection limits at least in one sample. Consequently, the $\mathrm{Li} / \mathrm{Ti}$ and $\mathrm{Ta} / \mathrm{W}$ ratios were used to distinguish among the different topaz types, fixing all data below detection as being arbitrarily equal to the limit of detection, in order to avoid dividing by zero. A plot of the Li/Ti ratio in function of W/Ta (Figure 12b) permits to segregate two topaz groups. These correspond to igneous topaz in the Beauvoir granite and hydrothermal topaz II of the polyphased vein on the one hand, and, on the other hand, to the hydrothermal topaz I of the polyphased vein plus all other topaz found in the stockwork (Figure 12b). This confirms the existence of at least two generations of hydrothermal topaz. 


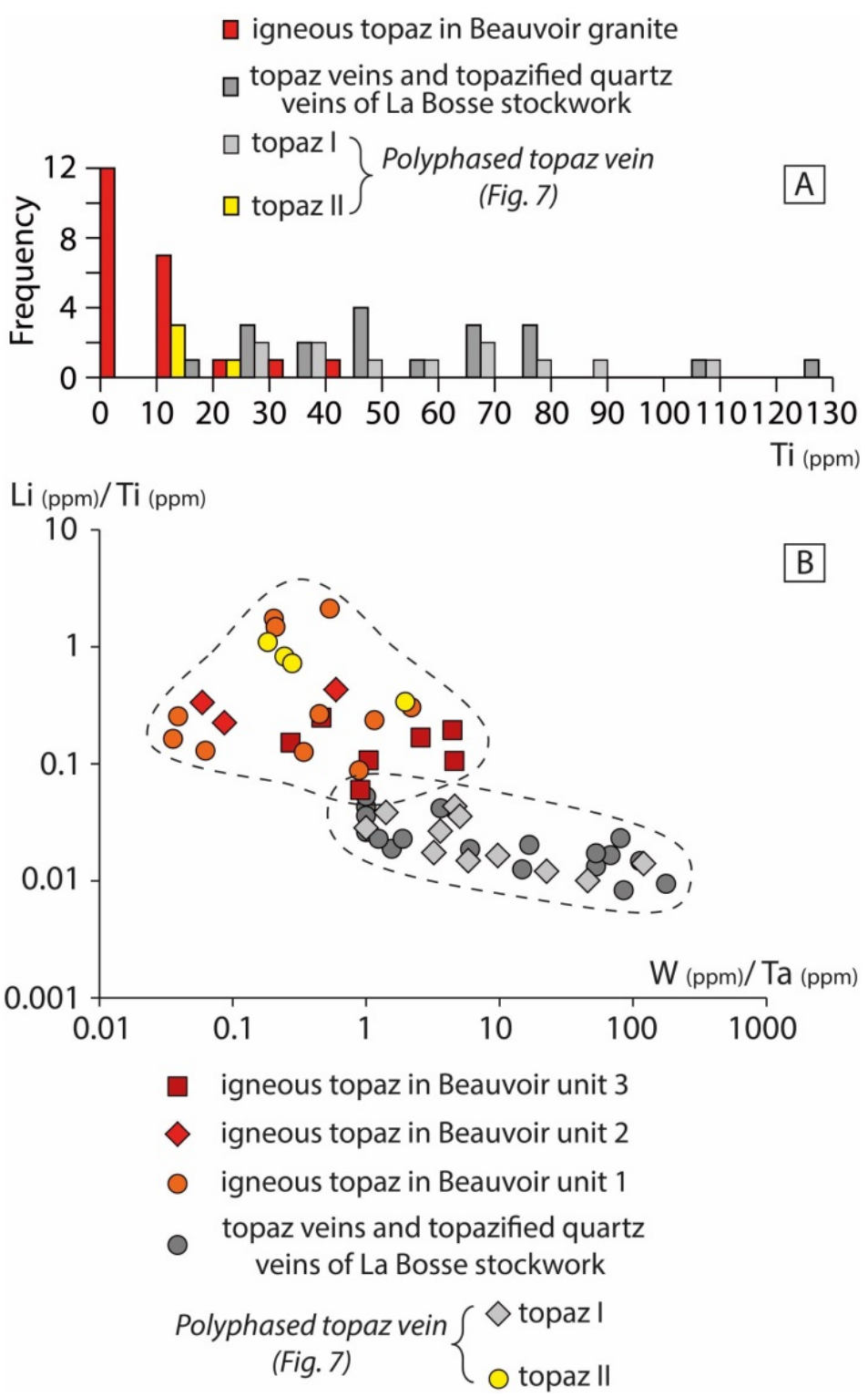

Figure 12. (A): A frequency histogram showing the variation of Ti content in the different topaz types, determined by LA-IC-PMS analyses. (B): A binary plot of Li/Ti vs W/Ta, which allows to distinguish two groups of topaz: igneous topaz from Beauvoir granite plus the hydrothermal topaz II generation from the polyphased topaz vein in the La Bosse stockwork (Figure 7), and all other topaz occurrences from the stockwork (including topaz I from the polyphased vein, and vein topaz and from topazified quartz veins). See [24] for a description of Beauvoir units 1 to 3.

\section{Discussion}

Textural relationships as well as the chemistry of wolframite point toward the presence of three episodes of wolframite mineralization in the Beauvoir area (Figure 13), and that wolframite in the Mazet veins is equivalent to wolframite $c$. Trace element chemistry also allows the distinction of two generations of hydrothermal topaz in the stockwork, topaz I and topaz II, respectively contemporaneous with wolframite $b$ and $c$. Moreover, hydrothermal topaz II, texturally younger than topaz I, shows similar chemistry to the magmatic topaz in the Beauvoir granite. A detailed paragenesis is available in the Supplementary Material (Figure S1). 

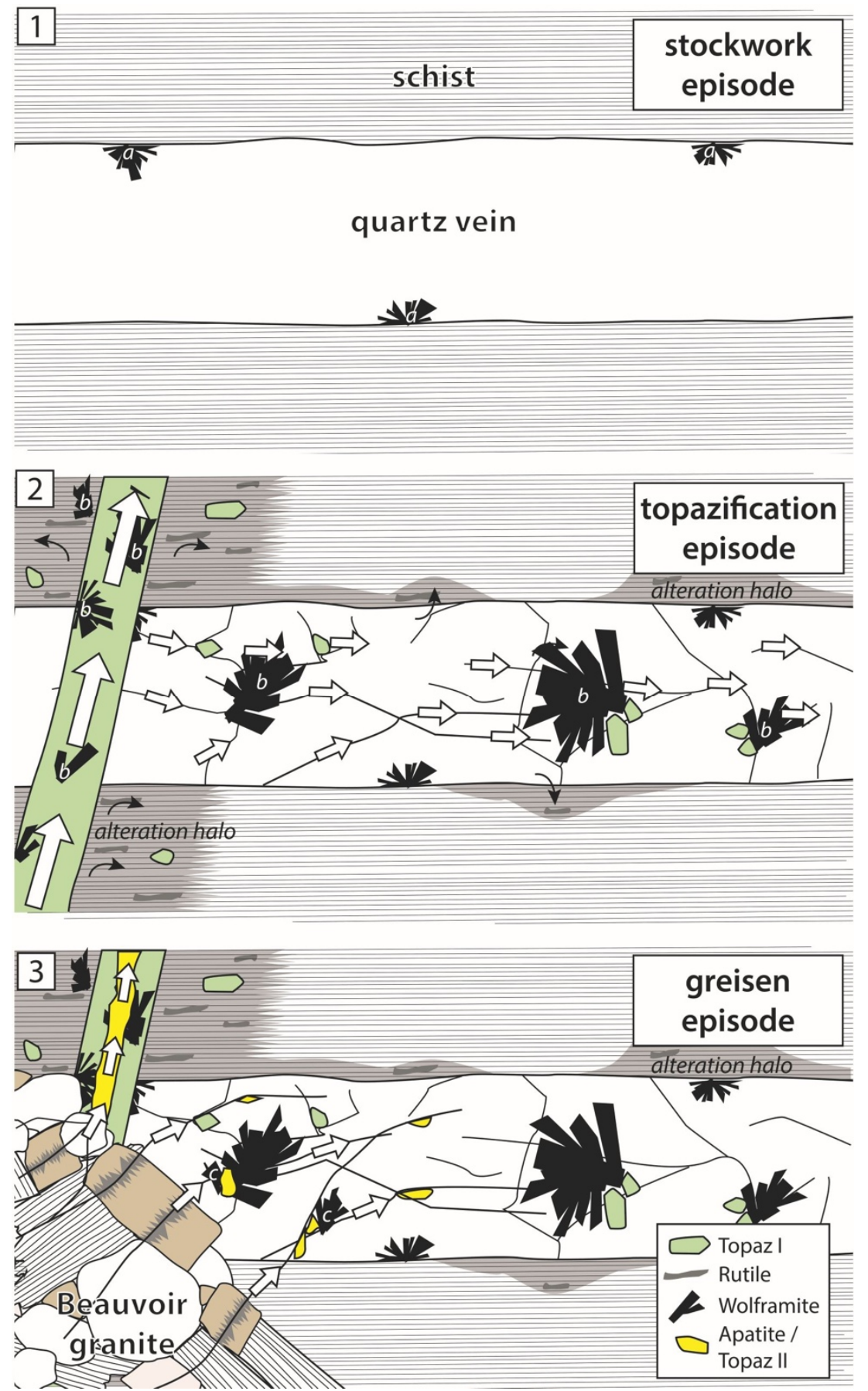

Figure 13. A schematic illustration depicting the succession of the three wolframite mineralizing episodes in the La Bosse stockwork. Emplacement of quartz veins in schist during formation of the stockwork, with precipitation of wolframite $a$. A silica-undersaturated F-rich alteration episode induced formation of topaz veins, topazification of pre-existing quartz veins, and metasomatism in the schist. Abundant wolframite $b$ precipitation occurred during this stage. Emplacement of the Beauvoir granite and subsequent greisen alteration produced further fluid circulation, which affected the stockwork, in a limited way only, by precipitating topaz (II) in reactivated topaz veins, as well as apatite and wolframite $c$ in quartz veins. 


\subsection{Paragenesis and Relative Chronology}

\subsubsection{Stockwork Episode}

The La Bosse stockwork is the first hydrothermal episode recorded in the district. It consists of quartz and wolframite $a \pm$ tourmaline \pm Bi-bearing minerals. Crosscutting relationships indicate that it is contemporaneous to potassic feldspar-dominated aplitic dykes. Wolframite $a$-bearing quartz veins, as well as these dykes, were subjected to the regional metamorphism event that affected the host rocks in the area, dated at $\sim 360 \mathrm{Ma}$ [36]. Tourmaline and ilmenite, located in schist near quartz veins, all texturally anterior (or contemporaneous) to metamorphism, are considered to have precipitated during quartz vein formation, as is the case for other wolframite-rich stockwork occurrences [43]. Consequently, formation of the La Bosse quartz veins and dykes took place more than likely before the regional metamorphic event.

\subsubsection{Topazification Episode}

After metamorphism, the La Bosse stockwork and dykes were affected by an episode of topazification (topaz I; 334 Ma based on wolframite $b$ dating [7]), which led to the formation of topaz veins and to massive replacement of quartz by topaz plus lepidolite-biotite solid solution, wolframite $b$ and rutile, and minor amounts of colombo-tantalite and cassiterite. Intensive metasomatism is evident in vein selvages, with replacement of metamorphic biotite in the schist host by lepidolite and variably intensive precipitation of topaz and accompanying minerals. Some wolframite $b$ crystals were also found isolated in quartz veins that underwent only minor topazification. Nevertheless, textural evidence, such as quartz recrystallization near the wolframite $b$ crystals, grain deformation, and other evidence of subsequent fluid flow such as fluid-inclusion and secondary mica-filled trails, indicate that wolframite precipitated after the quartz veins had formed.

\subsubsection{Greisen Episode}

Field observations indicate that both the Beauvoir and Colettes granites crosscut the above-mentioned topaz veins as well as the La Bosse quartz veins, which is consistent with the younger age determined for the former two plutons ( 312 Ma). Evidence for an orthomagmatic episode at the end of Beauvoir crystallization is not extensive in the area and takes the form of minor occurrences of secondary cassiterite and colombo-tantalite in the host schist at and near its contact with the Beauvoir granite. A fluid inclusion study outlined the evolution of this magmatic fluid [25], which consisted of an initial moderately saline brine exsolved from the Beauvoir granite at $>550{ }^{\circ} \mathrm{C}$. An intense boiling episode initiated the segregation of two fluids: a strongly saline brine and a low-salinity aqueous fluid. Two studies [24,25] proposed that the latter was responsible for the greisen alteration, after possible mixing with a meteoric fluid [44].

Greisen alteration substantially affected the apical parts of the Beauvoir and Colettes granites. This alteration consisted of replacement of magmatic minerals (alkali feldspar \pm quartz \pm lepidolite, depending on the local intensity of alteration) by hydrothermal muscovite, quartz \pm apatite and rare colombo-tantalite, and was accompanied by emplacement of quartz veins. An uncommon feature of this greisen, with respect to typical greisen alteration, is the local occurrence of large proportions of apatite. Similarly, unusual are the proportions of topaz, which is systematically scarce or altogether absent where either granite is affected by greisen alteration. On the other hand, greisen alteration in the stockwork area precipitated significantly higher amounts of topaz (topaz II), which, because of its occurrence next to topaz I, is tentatively interpreted as deriving from dissolution/recrystallization of this generation. In addition, small amounts of wolframite $c$, plus apatite, crystallized within the altered quartz veins of the stockwork. The greisen fluid is also at the origin of the proximal quartz veins that are located in or at the immediate proximity of the Beauvoir and Colettes granites. These veins only bear minor amounts of colombo-tantalite, cassiterite and wolframite, except in the Mazet area, where they contain large proportions of wolframite $c$. 


\subsubsection{Kaolinization Episode}

Besides field evidence indicating that the widespread kaolinization post-dated all other events, there are no constraints as to its precise age. The fact that this alteration is confined to zones in the Beauvoir and Colettes granites that had been previously affected by greisen alteration may be due to the abundant presence of muscovite, which is easily altered to kaolinite. Also, significant porosity created by the greisen alteration [45] could considerably enhance the circulation of the fluids responsible for kaolinization. During this episode, a last generation of quartz veins, called "late quartz vein" was emplaced in the granite [24]. Locally, the kaolinite alteration also affected the stockwork, as evidenced by the replacement of wolframite by W-rich goethite and kaolinite.

\subsection{Source, Reservoir and Remobilization of $W$}

In the above paragraphs we have understood the distribution of the different wolframite generations in the different lithologies (Table 2). The earliest $\mathrm{W}$ generation, wolframite $a$, occurs only in the La Bosse stockwork. The presence of contemporaneous potassic feldspar-rich aplitic dykes and quartz veins suggests a porphyry affinity to this stockwork system, and occurrence of felsic-intrusive rocks of porphyry affinity in the Echassières region are described in [23]. If this were the case, it is probable that $\mathrm{W}$ to form wolframite $a$ is of orthomagmatic origin. Although this wolframite only occurs in very low amounts, it may initially have been more abundant with most of it dissolved during metamorphism or during the later alteration/recrystallization occurring during topazification and greisenization of the Beauvoir granite. The common presence of corrodes edges on wolframite $a$ corroborates this (cf. Figure 4). Following through, during these respective hydrothermal episodes, part of wolframite $a$ may have been remobilised to form wolframite $b$ and wolframite $c$.

Table 2. Distribution of the different types of wolframite and of late W-rich goethite in the Echassières district.

\begin{tabular}{|c|c|c|}
\hline $\begin{array}{c}\text { Mineralization } \\
\text { Type }\end{array}$ & Location & $\begin{array}{c}\text { Principal Accompanying } \\
\text { Minerals }\end{array}$ \\
\hline Wolframite $a$ & Quartz vein of La Bosse stockwork. & $\begin{array}{l}\text { quartz, tourmaline, } \\
\text { ilmenite, bismuth metal. }\end{array}$ \\
\hline Wolframite $b$ & $\begin{array}{l}\text { - Topaz vein. } \\
\text { - Topazified, altered or recrystallized quartz veins of La } \\
\text { Bosse stockwork. } \\
\text { - Metasomatized schist. }\end{array}$ & $\begin{array}{l}\text { topaz I, lepidolite/F-biotite } \\
\text { series, rutile. }\end{array}$ \\
\hline Wolframite $c$ & $\begin{array}{l}\text { - } \quad \text { Altered (geisenized) quartz vein of La Bosse stockwork. } \\
\text { - Mazet vein. }\end{array}$ & $\begin{array}{l}\text { quartz, apatite, muscovite, } \\
\text { topaz II. }\end{array}$ \\
\hline W-rich goethite & $\begin{array}{l}\text { Small quantities in all altered rocks of Echassières district: } \\
\text { - } \quad \text { Dykes, veins and schist of La Bosse stockwork. } \\
\text { - } \quad \text { Altered Beauvoir and Colettes granites and veins within. } \\
\text { - } \quad \text { Fractured proximal veins. }\end{array}$ & $\begin{array}{l}\text { kaolinite, quartz, } \\
\text { gorceixite, Mn-oxide. }\end{array}$ \\
\hline
\end{tabular}

The major deposition stage of $W$ in the Echassières district is represented by wolframite $b$ (Table 3). The origin of $\mathrm{W}$ to form this generation is less clear: it could be derived from a deeply-seated hidden granite, or from massive alteration/recrystallization of wolframite $a$, or a combination of the two. Either way, the large amount of topaz associated with wolframite $b$ suggests circulation of an acidic and F-rich fluid, clearly deriving from an evolved, peraluminous granite [46,47].

In view of the high amount of $\mathrm{W}$ in the Beauvoir and Colettes granites [27], these bodies are certainly the source of $\mathrm{W}$ for wolframite $c$. However, the only important occurrences of wolframite $c$ are found in the Mazet veins, while in the Beauvoir greisen and in the La Bosse stockwork, wolframite 
$c$ is rare. Some evidence does exist showing that during the greisen episode wolframite $c$ may replace earlier formed wolframite $a$ or $b[25,48]$, but such occurrences are uncommon. We have seen above that the Mazet veins were likely formed from the same fluids that formed the greisen (see also [24]), suggesting that $\mathrm{W}$ remained mostly in solution during alteration of the granites and greisen fluid percolation. Presence of micro-quartz within vein cores in the Mazet veins contrasts with the $\mathrm{cm}$-sized euhedral quartz typical of the other proximal veins. This texture has been recognised as indicative of crystallization during intense boiling (or flashing; [49]), a mechanism that is known to destabilise aqueous $\mathrm{W}$ complexes and favour wolframite precipitation [50,51]. This process provides an explanation as to the abundant presence of wolframite in the Mazet veins, which differs from other proximal veins in the district.

Kaolinization had only a minor impact on the wolframite in the quartz veins. Conversely, the majority of wolframite located in the metasomatized schist is partially to totally pseudomorphosed to W-rich goethite. Nevertheless, in quartz veins of La Bosse stockwork that underwent late fracturing, partial alteration of wolframite to goethite was observed locally. Crystallization of W-rich goethite in the absence of wolframite (late quartz veins, kaolinized granite) suggests at least partial remobilisation of W during this late episode. As evidenced in [41,42], the chemistry of goethite appears to be a good indicator for the proximity of a $\mathrm{W}$ source. This is consistent with the $\mathrm{WO}_{3}$ measured in goethite at Echassières, which varies inversely to the distance from mineralized rocks. Similarly, $\mathrm{Al}$ and $\mathrm{P}$ incorporation in goethite appear to be controlled by the proximity of the Beauvoir granite (Figure 11).

Table 3. Rough estimation of the different proportions of wolframite types as a function of their location in the Echassières district.

\begin{tabular}{ccccc}
\hline \multirow{2}{*}{ Generation } & \multicolumn{3}{c}{ Estimated Proportions of Wolframite Types in Different Localities } \\
\cline { 2 - 5 } & $\begin{array}{c}\text { Stockwork Above } \\
\text { Beauvoir Granite }\end{array}$ & $\begin{array}{c}\text { Stockwork Below } \\
\text { Beauvoir Granite }\end{array}$ & Mazet Veins & $\begin{array}{c}\text { Echassières } \\
\text { District (Total) }\end{array}$ \\
\hline Wolframite $\boldsymbol{a}$ & $5 \%$ & $20 \%$ & $0 \%$ & ca. $10 \%$ \\
\hline Wolframite $\boldsymbol{b}$ & $95 \%$ & $80 \%$ & $0 \%$ & ca. $80 \%$ \\
\hline Wolframite $c$ & $<1 \%$ & $0 \%$ & $100 \%$ & ca. $10 \%$ \\
\hline
\end{tabular}

\subsection{Comparison with the Literature}

This study confirms known results and adds new evidence concerning the multistage W-mineralization in the Echassières district. Previous studies $[25,48]$ report a variation in the ferberite/hubnerite component $(\mathrm{Fe} / \mathrm{Mn}$ ) ratio in wolframite from the La Bosse stockwork (with $\mathrm{Fe} / \mathrm{Mn}$ ratios varying from c.a. 10 to 3.3). It is now clear that this variation reflects the presence of wolframite $a$ and $b$ generations determined in our study (with Fe/Mn ratios of 8.4 and 3.5, respectively). They also recognized that the most abundant wolframite is chemically zoned with alternating $\mathrm{Nb}$-rich and $\mathrm{Nb}$-poor band, which is a typical characteristic of wolframite $b$ (this study). However, because these authors did not separate the two wolframite generations, they assumed that all $\mathrm{W}$ precipitated during the stockwork episode. They ascribed topazification to an event posterior to wolframite crystallization, supposedly triggered by cooling of the Beauvoir granite. Since their work, the evolution of characterization technics (e.g., improvement of SEM and cathodoluminescence imagery) has permitted us to recognize that wolframite $b$ postdates the stockwork episode and precipitated concomitantly to the hydrothermal topaz I (topazification episode). Nevertheless, a second generation of topaz, identified in this study (topaz II), did form during the greisen alteration of the Beauvoir granite. These studies $[25,48]$ also highlight the uncommon replacement of wolframite $b$ by another type of wolframite of near-end-member hubnerite composition (wolframite $c$ in our study) in the stockwork. The presence of hubnerite as the only wolframite type in the Mazet veins was also reported [23]. More recently, however, work on the Echassieres W mineralization by Harlaux and coworkers $[7,40]$ did not distinguish wolframite from the La Bosse stockwork from that of the Mazet veins, which led them to 
proposing a unique origin and age for the $\mathrm{W}$ mineralization in the district. This apparent contradiction may have arisen from the fact that, historically, the ores from the La Bosse stockwork and from the Mazet veins were sorted in the same site (Montmins [23]). As mentioned, samples for Mazet are only available from a collection, thus it likely that their Mazet sample (MTM-1) was actually a rock from the stockwork. Indeed, the Mazet wolframite described in Harlaux's studies [7,40] shares many characteristics with that from the La Bosse stockwork-wolframite $b$ in our study-i.e., colour, low hubnerite/ferberite ratio, $\mathrm{Nb}$-rich zoning, trace element chemistry, and an age ( 334 Ma [7]) identical to the stockwork wolframite but older than the Colettes (312 $\pm 8 \mathrm{Ma}$ by Rb-Sr on whole rock [30]) and Beauvoir granites ( 310 Ma), which are crosscut by the Mazet vein.

The occurrence of three different wolframite types in the Echassières district was not previously reported, although the possible presence of several generations could have been inferred by careful analysis of the older literature. This is now clearly demonstrated. Moreover, we highlight that the three wolframite types do not simply represent three $\mathrm{W}$-precipitation phases during one mineralization episode but distinguish three $\mathrm{W}$-mineralization events related to three distinct hydrothermal episodes that took place at different ages and magmatic/tectonic settings in the Variscan belt. This rather remarkable W-mineralization history makes the Echassières district a unique case, with, to our knowledge, no analogue worldwide.

\subsection{Evolution of Fe/Mn Ratio for the Different Types of Wolframite}

Because of Fe depletion in peraluminous magma during fractional crystallization [52], and because hydrothermal fluids can become enriched in Fe from interacting with the host rock (e.g., [15]), in stockwork or porphyry settings the Fe/Mn ratio in wolframite can be a good indicator of the degree of differentiation of the magmatic source, as well as of the extent of orthomagmatic input on the fluid composition and, consequently, on the mineralization [53]. The lower the Fe/Mn ratio, the more evolved the magmatic source should be (rare metal granite or pegmatite), and/or the more wolframite mineralization is controlled by a magmatic fluid (proximal or intragranitic deposit; i.e., host-rock assimilation by the fluid is limited).

In our system, wolframite $a$ shows very high $\mathrm{Fe} / \mathrm{Mn}$, which was expected given that this generation is interpreted to be related to formation of the stockwork/porphyry deposit (least evolved magma), and to extensive fluid-rock interaction. The Fe/Mn of wolframite $b$ is comparatively lower. This generation is related to a F-rich, acidic fluid, which suggests an orthomagmatic signature, from an evolved magma. However, this Fe/Mn ratio remains moderate, because of the distal nature of wolframite $b$ mineralization from the (concealed) granitic source. The latest generation, wolframite $c$, displays low $\mathrm{Fe} / \mathrm{Mn}$ ratio. This is consistent with an origin from the highly evolved Beauvoir granite, despite the location of these veins away from the granite. Indeed, using the trace-element signature of quartz it was possible to show that greisen alteration of Beauvoir and quartz veins from the Mazet prospect originated from the same fluid, without significant interaction with the host rock [24].

\section{Conclusions}

A detailed petrographic and geochemical study of $\mathrm{W}$ mineralization confirms the occurrence of three distinct episodes of wolframite crystallization in the Echassières district, plus later remobilization by supergene fluid during kaolinization, recorded by W-rich goethite. Tungsten mineralization at Echassières was multistage. It started before regional metamorphism, during emplacement of a porphyry related stockwork (wolframite $a$ ). Ore deposition (wolframite $b$ ) was the most efficient (wolframite $b$ ) during post-metamorphic hydrothermal alteration caused by acidic F-rich orthomagmatic fluids, sourced from an evolved peraluminous granite. There followed emplacement of the Beauvoir rare-metal granite, which triggered alteration of the surrounding rocks by greisen fluids, promoting precipitation of the third wolframite generation $(c)$. Supergene alteration affected most of these rocks, involving $\mathrm{W}$ remobilization and precipitation of $\mathrm{W}$-bearing goethite after wolframite. 
Only a few age determinations are available for the Echassières complex (Barrovian metamorphism, granites and wolframite $b$ ), some of which controversial. There is thus a need for further research on the Echassières district to focus on providing solid age determinations for the episodes identified in this study, in order to provide an enhanced genetic model for this unique setting. Similarly, the origin of the "MTM-1" wolframite sample, described as originating from the Mazet area in recent studies $[7,40]$ is highly controversial.

This study has implications on a global scale; evidence for alteration by fluids from evolved granitic bodies (e.g., presence of topaz, greisen like) could help targeting $\mathrm{W}$ ore, as shown for the Echassières district and $\mathrm{W}$ deposits in Cornwall and Eastern China. It should also be kept in mind that greisen-related $\mathrm{W}$ mineralization may overprint previous mineralizing events that could have played an important role in the development of a deposit. Finally, our work demonstrates that $\mathrm{W}$ content in goethite from supergene alteration can be used to fingerprint $\mathrm{W}$ mineralization efficiently.

Supplementary Materials: The following material is available online at http://www.mdpi.com/2075-163X/9/10/ 637/s1: Table S1. Chemical data: EPMA analyses of wolframite and goethite and LA-ICP-MS analyses of topaz. Figure S1. Mineral paragenesis for the different episodes that affected the Echassières district in the Beauvoir and Colettes granites and the La Bosse stockwork $(\mathrm{A})$, and in the proximal veins and schist host rock (B). For best visibility, the metamorphic minerals (Metam.) are not listed in (B), as they are the same as in (A). Age compilation after $[19-21,29,30]$.

Author Contributions: Conceptualization, L.M.; methodology, L.M.; validation, J.M., D.B., L.B. and S.S.; formal analysis, P.d.P., S.G. and P.L.; investigation, L.M.; writing-original draft preparation, L.M. and S.S.; writing-review and editing, J.M., L.B. and D.B.; visualization, L.M.; supervision, J.M., D.B., L.B. and S.S.; project administration, J.M., D.B., L.B. and S.S.; funding acquisition, J.M. and L.B.

Funding: This research was funded by BRGM (French geological survey), the University of Toulouse "Paul Sabatier" and the CNRS (French National Center for Scientific Research).

Acknowledgments: The authors are grateful to Thierry Aigouy for providing help on the SEM observations, and to Olivier Vanderhaeghe, Margot Munoz and Eric Gloaguen, for valuable critical discussion. Critical reviews by three anonymous referees have considerably improved the quality of this manuscript.

Conflicts of Interest: The authors declare no conflict of interest.

\section{References}

1. European Commission. Report on Critical Raw Materials for the EU, 2014; European Commission: Brussels, Belgium, 2014; pp. 1-92.

2. European Commission. Study on the Review of the List of Critical Raw Materials, 2017; European Commission: Brussels, Belgium, 2017; pp. 1-92. [CrossRef]

3. Brown, T.; Pitfield, P. Tungsten. In Critical Metals Handbook; Gun, G., Ed.; Wiley: Hoboken, NJ, USA, 2013; pp. 385-413.

4. Mlynarczyk, M.S.J.; Williams-Jones, A.E. The role of collisional tectonics in the metallogeny of the central Andean tin belt. Earth Planet Sci. Lett. 2005, 240, 656-667. [CrossRef]

5. Dewaele, S.; De Clercq, F.; Hulsbosch, N.; Piessens, K.; Boyce, A.; Burgess, R.; Muchez, P. Genesis of the vein-type tungsten mineralization at Nyakabingo (Rwanda) in the Karagwe-Ankole belt, Central Africa. Miner. Depos. 2016, 51, 283-307. [CrossRef]

6. Zhao, W.W.; Zhou, M.F.; Li, Y.H.M.; Zhao, Z.; Gao, J.F. Genetic types, mineralization styles, and geodynamic settings of Mesozoic tungsten deposits in South China. J. Asian Earth Sci. 2017, 137, 109-140. [CrossRef]

7. Harlaux, M.; Romer, R.L.; Mercadier, J.; Morlot, C.; Marignac, C.; Cuney, M. 40 Ma of hydrothermal W mineralization during the Variscan orogenic evolution of the French Massif Central revealed by U-Pb dating of wolframite. Miner. Depos. 2017, 53, 21-51. [CrossRef]

8. Pirajno, F. (Ed.) Intrusion-Related hydrothermal mineral systems. In Hydrothermal Processes and Mineral Systems; Springer Science \& Business Media: Berlin, Germany, 2008; pp. 205-354.

9. Marignac, C. Geologic, fluid inclusions, and stable isotope studies of the tin-tungsten deposits of Panasqueira, Portugal: Discussion. Econ. Geol. 1982, 77, 1263-1266. [CrossRef] 
10. Polya, D.A.; Foxford, K.A.; Stuart, F.; Boyce, A.; Fallick, A.E. Evolution and paragenetic context of low $\delta D$ hydrothermal fluids from the Panasqueira W-Sn deposit, Portugal: New evidence from microthermometric, stable isotope, noble gas and halogen analyses of primary fluid inclusions. Geochim. Cosmochim. Acta 2000, 64, 3357-3371. [CrossRef]

11. Burnard, P.G.; Polya, D.A. Importance of mantle derived fluids during granite associated hydrothermal circulation: He and Ar isotopes of ore minerals from Panasqueira. Geochim. Cosmochim. Acta 2004, 68, 1607-1615. [CrossRef]

12. Chicharro, E.; Boiron, M.C.; López-García, J.Á.; Barfod, D.N.; Villaseca, C. Origin, ore forming fluid evolution and timing of the Logrosán Sn-(W) ore deposits (Central Iberian Zone, Spain). Ore Geol. Rev. 2016, 72, 896-913. [CrossRef]

13. Carocci, E.; Marignac, C.; Cathelineau, M.; Truche, L.; Lecomte, A.; Pinto, F. Rutile from Panasqueira (Central Portugal): An excellent pathfinder for wolframite deposition. Minerals 2019, 1, 9. [CrossRef]

14. Breiter, K.; Förster, H.J.; Seltmann, R. Variscan silicic magmatism and related tin-tungsten mineralization in the Erzgebirge-Slavkovský les metallogenic province. Miner. Depos. 1999, 34, 505-521. [CrossRef]

15. Lecumberri-Sanchez, P.; Vieira, R.; Heinrich, C.A.; Pinto, F.; Wälle, M. Fluid-rock interaction is decisive for the formation of tungsten deposits. Geology 2017, 45, 579-582. [CrossRef]

16. Mao, Z.; Cheng, Y.; Liu, J.; Yuan, S.; Wu, S.; Xiang, X.; Luo, X. Geology and molybdenite Re-Os age of the Dahutang granite-related veinlets-disseminated tungsten ore field in the Jiangxin Province, China. Ore Geol. Rev. 2013, 53, 422-433. [CrossRef]

17. Xie, L.; Wang, R.C.; Che, X.D.; Huang, F.F.; Erdmann, S.; Zhang, W.L. Tracking magmatic and hydrothermal $\mathrm{Nb}-\mathrm{Ta}-\mathrm{W}-\mathrm{Sn}$ fractionation using mineral textures and composition: A case study from the late Cretaceous Jiepailing ore district in the Nanling Range in South China. Ore Geol. Rev. 2016, 78, 300-321. [CrossRef]

18. Zhou, J.; Feng, C.; Li, D.; Li, G. Geological, geochemical, and geochronological characteristics of Caledonian W-Sn mineralization in the Baiganhu orefield, southeastern Xinjiang, China. Ore Geol. Rev. 2016, 75, 125-149. [CrossRef]

19. Zhang, Y.; Gao, J.F.; Ma, D.; Pan, J. The role of hydrothermal alteration in tungsten mineralization at the Dahutang tungsten deposit, South China. Ore Geol. Rev. 2018, 95, 1008-1027. [CrossRef]

20. Jackson, N.J.; Willis-Richards, J.; Manning, D.A.; Sams, M.S. Evolution of the Cornubian ore field, Southwest England; Part II, Mineral deposits and ore-forming processes. Econ. Geol. 1989, 84, 1101-1133. [CrossRef]

21. Chesley, J.T.; Halliday, A.N.; Snee, L.W.; Mezger, K.; Shepherd, T.J.; Scrivener, R.C. Thermochronology of the Cornubian batholith in southwest England: Implications for pluton emplacement and protracted hydrothermal mineralization. Geochim. Cosmochim. Acta 1993, 57, 1817-1835. [CrossRef]

22. Williamson, B.J.; Stanley, C.J.; Wilkinson, J.J. Implications from inclusions in topaz for greisenisation and mineralization in the Hensbarrow topaz granite, Cornwall, England. Contrib. Miner. Petrol. 1997, 127, 119-128. [CrossRef]

23. Aubert, G. Les Coupoles Granitiques de Montebras et d'Echassières (Massif Central Français) et la Genèse de Leur Minéralisation en Étain, Lithium, Tungsten et Béryllium; B.R.G.M. Mémoires: Paris, France, 1969; p. 345.

24. Monnier, L.; Lach, P.; Salvi, S.; Melleton, J.; Bailly, L.; Beziat, D.; Monnier, Y.; Gouy, S. Quartz trace-element composition by LA-ICP-MS as proxy for granite differentiation, hydrothermal episodes, and related mineralization: The beauvoir granite (Echassières district), France. Lithos 2018, 320, 355-377. [CrossRef]

25. Cuney, M.; Marignac, C.; Weisbrod, A. The Beauvoir topaz-lepidolite albite granite (Massif Central, France); the disseminated magmatic Sn-Li-Ta-Nb-Be mineralization. Econ. Geol. 1992, 87, 1766-1794. [CrossRef]

26. Duthou, J.L.; Pin, C. Etude isotopique Rb/Sr de l'apex granitique d'Echassières. Géol. Fr. 1987, 2, $63-67$.

27. Raimbault, L.; Cuney, M.; Azencott, C.; Duthou, J.L.; Joron, J.L. Geochemical evidence for a multistage magmatic genesis of Ta-Sn-Li mineralization in the granite at Beauvoir, French Massif Central. Econ. Geol. 1995, 90, 548-576. [CrossRef]

28. Merceron, T.; Vieillard, P.; Fouillac, A.M.; Meunier, A. Hydrothermal alterations in the Echassieres granitic cupola (Massif Central, France). Contrib. Miner. Petrol. 1992, 112, 279-292. [CrossRef]

29. Cheilletz, A.; Archibald, D.A.; Cuney, M.; Charoy, B. Ages 40Ar/39Ar du leucogranite à topaze-lépidolite de Beauvoir et des pegmatites sodolithiques de Chédeville (Nord du Massif Central, France). Signification pétrologique et géodynamique. C. R. Acad. Sci. 1992, 315, 329-336.

30. Pin, C. Sr-Nd isotopic study of igneous and metasedimentary enclaves in some Hercynian granitoids from the Massif Central, France. Dev. Petrol. 1991, 13, 333-343. 
31. Rossi, P.; Autran, A.; Azencott, C.; Burnol, L.; Cuney, M.; Johan, V.; Raimbault, L. Logs pétrographiques et géochimiques du granite de Beauvoir dans le sondage GPF "Echassières I": Minéralogie et géochimie comparée. Géol. Fr. 1987, 2, 111-135.

32. Ledru, P.; Lardeaux, J.M.; Santallier, D.; Autran, A.; Quenardel, J.M.; Floc'h, J.P.; Ploquin, A. Où sont les nappes dans le Massif central français? Bull. Soc. Géol. Fr. 1989, 3, 605-618. [CrossRef]

33. Faure, M.; Mézème, E.B.; Duguet, M.; Cartier, C.; Talbot, J.Y. Paleozoic tectonic evolution of medio-Europa from the example of the French Massif Central and Massif Armoricain. J. Virt. Expl. 2005, 19, 1-25. [CrossRef]

34. Schulz, B.; Triboulet, C.; Audren, C.; Feybesse, J.L. PT-paths from metapelite garnet zonations, and crustal stacking in the Variscan inverted metamorphic sequence of La Sioule, French Massif Central. Z. Dtsch. Geol. Ges. 2001, 152, 1-26.

35. Schulz, B. EMP-monazite age controls on PT paths of garnet metapelites in the Variscan inverted metamorphic sequence of La Sioule, French Massif Central. Bull. Soc. Géol. Fr. 2009, 180, 271-282. [CrossRef]

36. Do Couto, D.; Faure, M.; Augier, R.; Cocherie, A.; Rossi, P.; Li, X.H.; Lin, W. Monazite U-Th-Pb EPMA and zircon $\mathrm{U}-\mathrm{Pb}$ SIMS chronological constraints on the tectonic, metamorphic, and thermal events in the inner part of the Variscan orogen, example from the Sioule series, French Massif Central. Int. J. Earth Sci. 2016, 105, 557-579. [CrossRef]

37. Melleton, J.; Gloaguen, E.; Frei, D. Rare-Elements (Li-Be-Ta-Sn-Nb) Magmatism in the European Variscan Belt: A Review. In Proceedings of the 13th Biennial SGA Meeting, Nancy, France, $24-27$ August 2015; pp. 24-27.

38. Pearce, N.J.; Perkins, W.T.; Westgate, J.A.; Gorton, M.P.; Jackson, S.E.; Neal, C.R.; Chenery, S.P. A compilation of new and published major and trace element data for NIST SRM 610 and NIST SRM 612 glass reference materials. Geostand. Geoanal. Res. 1997, 21, 115-144. [CrossRef]

39. Wang, R.C.; Fontan, F.; Monchoux, P. Minéraux disséminés comme indicateurs du caractère pegmatitique du granite de Beauvoir, Massif d'Echassières, Allier, France. Can. Mineral 1992, 30, 763-770.

40. Harlaux, M.; Mercadier, J.; Marignac, C.; Peiffert, C.; Cloquet, C.; Cuney, M. Tracing metal sources in peribatholitic hydrothermal $\mathrm{W}$ deposits based on the chemical composition of wolframite: The example of the Variscan French Massif Central. Chem. Geol. 2018, 479, 58-85. [CrossRef]

41. Tarassov, M.; Mihailova, B.; Tarassova, E.; Konstantinov, L. Chemical composition and vibrational spectra of tungsten-bearing goethite and hematite from Western Rhodopes, Bulgaria. Eur. J. Mineral 2002, 14, 977-986. [CrossRef]

42. Kreissl, S.; Bolanz, R.; Göttlicher, J.; Steininger, R.; Tarassov, M.; Markl, G. Structural incorporation of W6+ into hematite and goethite: A combined study of natural and synthetic iron oxides developed from precursor ferrihydrite and the preservation of ancient fluid compositions in hematite. Am. Minerol. 2016, 101, 2701-2715. [CrossRef]

43. Launay, G.; Sizaret, S.; Guillou-Frottier, L.; Gloaguen, E.; Pinto, F. Deciphering fluid flow at the magmatic-hydrothermal transition: A case study from the world-class Panasqueira $\mathrm{W}-\mathrm{Sn}-(\mathrm{Cu})$ ore deposit (Portugal). Earth Planet Sci. Let. 2018, 499, 1-12. [CrossRef]

44. Fouillac, A.M.; Rossi, P. Near-solidus delta $18 \mathrm{O}$ depletion in a Ta-Nb-bearing albite granite; the Beauvoir Granite, France. Econ. Geol 1991, 86, 1704-1720. [CrossRef]

45. Launay, G.; Sizaret, S.; Guillou-Frottier, L.; Fauguerolles, C.; Champallier, R.; Gloaguen, E. Dynamic permeability related to greisenization reactions in $\mathrm{Sn}-\mathrm{W}$ ore deposits: Quantitative petrophysical and experimental evidence. Geofluids 2019. [CrossRef]

46. Webster, J.; Thomas, R.; Förster, H.J.; Seltmann, R.; Tappen, C. Geochemical evolution of halogen-enriched granite magmas and mineralizing fluids of the Zinnwald tin-tungsten mining district, Erzgebirge, Germany. Miner. Depos. 2004, 39, 452-472. [CrossRef]

47. Thomas, R.; Förster, H.J.; Rickers, K.; Webster, J.D. Formation of extremely F-rich hydrous melt fractions and hydrothermal fluids during differentiation of highly evolved tin-granite magmas: A melt/fluid-inclusion study. Contrib. Miner. Petrol. 2005, 148, 582-601. [CrossRef]

48. Aïssa, M.; Marignac, C.; Weisbrod, A. Le stockwerk à ferbérite d’Echassières: Évolution spatiale et temporelle; cristallochimie des ferbérites. Géol. Fr. 1987, 2, 311-333.

49. Moncada, D.; Mutchler, S.; Nieto, A.; Reynolds, T.J.; Rimstidt, J.D.; Bodnar, R.J. Mineral textures and fluid inclusion petrography of the epithermal Ag-Au deposits at Guanajuato, Mexico: Application to exploration. J. Geochem. Explor. 2012, 114, 20-35. [CrossRef] 
50. Davis, W.J.; Williams-Jones, A.E. A fluid inclusion study of the porphyry-greisen, tungsten-molybdenum deposit at Mount Pleasant, New Brunswick, Canada. Miner. Depos. 1985, 20, 94-101. [CrossRef]

51. Wood, S.A.; Samson, I.M. The hydrothermal geochemistry of tungsten in granitoid environments: I. Relative solubilities of ferberite and scheelite as a function of T, P, pH, and $\mathrm{m} \mathrm{NaCl}$. Econ. Geol. 2000, 95, 143-182. [CrossRef]

52. Bowen, N.L. The Evolution of the Igneous Rocks; Dover Publications: Mineola, NY, USA, 1956.

53. Michaud, J.A.S.; Pichavant, M. The H/F ratio as an indicator of contrasted wolframite deposition mechanisms. Ore Geol. Rev. 2019, 104, 266-272. [CrossRef]

(C) 2019 by the authors. Licensee MDPI, Basel, Switzerland. This article is an open access article distributed under the terms and conditions of the Creative Commons Attribution (CC BY) license (http://creativecommons.org/licenses/by/4.0/). 